\title{
ARTICLE \\ THE LONG ARM OF STATE AID LAW: CRUSHING CORPORATE TAX AVOIDANCE
}

\author{
Sandra Marco Colino*
}

\begin{abstract}
The sun is setting on the days when multinationals could establish intricate tax systems to drastically reduce their tax bills. Since the 1990s, the OECD and the EU have taken resolute steps to compel their members to eradicate corporate tax elusion and harmful tax competition. These solutions are forward-looking, and aim at averting future issues. Importantly, the European Commission has picked up a fight against past tax schemes by targeting tax rulings via State aid, a part of EU competition law. In the most publicized case, Apple was asked to pay US\$15 billion to Ireland in outstanding taxes. The decision was annulled by the General Court in July 2020, and an appeal before the Court of Justice is currently pending. This Article assesses the value of State aid law as a tool to fight unfair corporate taxation. It does so by scrutinizing the decisional practice of the Commission and the judgments of the General Court. The point of departure is that it is legitimate to resort to State aid rules to monitor tax planning practices. While the Commission faces an uphill struggle to win individual cases, the general principles and strategy delineated by the investigations serve to enhance deterrence and decrease undesirable predictability. Unintendedly, the Commission's losses reinforce the robustness of judicial review, and serve to question the narrative that EU competition law may be strategically applied against US tech giants. Overall, the

* Associate Professor, Faculty of Law, Chinese University of Hong Kong. Deputy Executive Director, Centre for Financial Regulation and Economic Development ("CFRED"). Member of the Academic Board, Dictum LLP. Winner of the 2020 Global Competition Review Academic Excellence Award. PhD, European University Institute, Florence, Italy. The work described in this Article was substantially supported by a grant from the General Research Fund of the Research Grants Council of the Hong Kong Special Administrative Region ("SAR"), China (Project No CUHK 14600718). I thank the experts and friends who have given me immensely valuable feedback on drafts of this Article. All errors are mine alone.
\end{abstract}


Article perceives State aid as a useful weapon to combat corporate tax malpractices, but as a complement, not a substitute, of the preferred tax harmonization strategy.

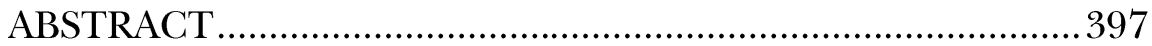

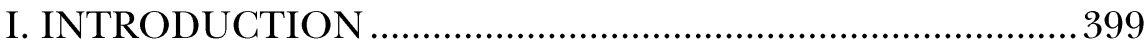

II. STATE AID AND COMPETITION ..................................... 403

A. State Aid Law: a European Affair? .............................. 404

B. Competition Concerns...............................................407

C. The EU Rules on State Aid ........................................410

1. General Legal Framework ......................................411

2. The Prohibition of Article 107(1) TFEU................412

a. "Intervention by the State or through State Resources".

b. "Liable to Affect Trade Between Member States"

c. "Distort or Threaten to Distort

Competition"

d. "Confer a [Selective] Advantage" .....................4 416

III. TAX RULINGS AND THE TAX DEALS OF

MULTINATIONAL COMPANIES

A. Understanding Tax Rulings

B. The Tax Arrangements of Multinational

Enterprises.

1. The Risks of Transfer (mis)Pricing. 423

2. The Harmful Effects of the Tax Schemes of MNEs

3. Traditional Means to Tackle Harmful Tax

Competition and Tax Avoidance

C. The Momentum for Action

IV. THE APPLICATION OF STATE AID LAW TO TAX

RULINGS: FIAT, STARBUCKS AND APPLE.................. 432

A. The EU's Tax Concerns and Competence to Act .......433

B. Regulating Direct Taxation at the EU Level................ 435

1. Non-Binding Measures ..........................................435

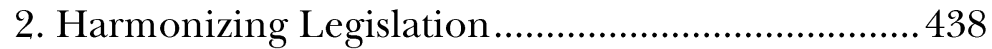

C. The EC's Application of State Aid Law to Tax

Rulings. 
1. The Tax Systems Endorsed

2. Application of Article 107-State Imputability, State Resources, Affection of Intra-EU Trade and Distortion of Competition............................. 445

3. Application of 107-Selective Advantage ............... 445

a. Luxembourg's Tax Ruling in Favor of Fiat....... 446

b. The Dutch APA for Starbucks.......................... 447

c. Apple's Tax Ruling in Ireland ...........................448

D. The General Court's Position...................................... 449

1. Disguised Harmonization? ..................................... 449

2. Demonstrating the Existence of a Selective

Advantage 451

a. Embracing the Arm's Length Principle

(With Caution).

b. Burden and Standard of Proof .....

V. STATE AID AS A TOOL TO COMBAT HARMFUL CORPORATE TAX PRACTICES: A CRITICAL ASSESSMENT 455

A. The Commission's Intended and Unintended

Victories 456

1. The ALP in the Context of State Aid Law 456

2. Pushing for National Legal Reform 459

3. Reducing Predictability 460

4. Unintended Outcomes: Probing Resilient

Narratives about EU Law 461

a. Technology Protectionism in the Application of EU Competition Law 461

b. The Thoroughness of the Judicial Review of EC Decisions 463

B. Sharpening the Commission's Axe: Considerations for Improvement................................................ 464

VI. CONCLUSION 465

\section{INTRODUCTION}

On July 15, 2020, the tech giant Apple grabbed headlines around the world when it won a highly publicized legal battle 
against the European Commission ("EC" or "Commission"). 1 Four years earlier, in the summer of 2016, the EC's Directorate General for Competition ("DG Comp") announced that certain tax benefits granted to the company in Ireland fell afoul of the European Union's ("EU") State aid rules. Apple would thus be required to pay over EU€13 billion (over US $\$ 15$ billion) to the Irish Tax and Customs Administration ("Irish Revenue").2

The whopping amount is the tax calculated to have been underpaid over more than two decades by virtue of an alleged preferential arrangement on corporate taxation. This "sweetheart deal," granted via two tax rulings, ${ }^{3}$ allowed Apple to dodge significant amounts of income tax by exploiting a loophole between the laws of Ireland and the United States. During a press conference held on the day the decision was issued, the EU's Competition Commissioner Margrethe Vestager illustratively explained that "for every million euro in profits, [Apple] paid just 500 euros in taxes." 4 The infinitesimal amount may be enough to get anyone's back up, and yet on appeal the General Court of the EU ("GC") annulled the EC's decision on the basis that the competition watchdog had failed to demonstrate the existence of a fundamental requirement for the application of State aid rules: a selective competitive advantage. 5

As soon as the judgment was announced, commentators rushed to weigh in on the outcome. Luis Garicano, Member of the European Parliament, described it as a "huge setback," and

1. Cases T-778/16 \& T-892/16, Ir. v. Comm'n, ECLI:EU:T:2020:338, paras. 505507 (July 15, 2020) [hereinafter Apple Judgment].

2. European Commission Press Release IP/16/2923, State Aid: Ireland Gave Illegal Tax Benefits to Apple Worth up to $€ 13$ billion (Aug. 30, 2016), http://europa.eu/rapid/press-release_IP-16-2923_en.htm [https://perma.cc/4AAT795L] (last visited Aug. 5, 2020); Commission Decision (EU) 2017/1283 of Aug. 30, 2016 on State Aid SA.38373 (2014/C) (ex 2014/NN0) (ex 2014/CP) Implemented by Ireland to Apple, 2017 O.J. (L 187) 1, 109 [hereinafter Apple Decision].

3. Apple Decision, supra note 2.

4. The video of the press conference is available at https://youtu.be/y2gTeRdiKtQ [https://perma.cc/3ZMH-EDYV] (last visited Aug. 5, 2020).

5. Apple Judgment, supra note 1. 
one which implies that the state aid route is "essentially dead."6 In a similar vein, Professor Ruth Mason of the University of Virginia called it a "major blow to the Commission's plan to use state aid to combat tax avoidance," but she agreed with the Apple win on the substance given the deficiencies in the EC's legal arguments. ${ }^{7}$ The ruling would not have sent shockwaves among those acquainted with the previous case law. Yet these statements may somewhat overestimate the crushing potential of the judgment on the prospect of relying on State aid rules to target direct corporate taxation. The GC makes it abundantly clear that it is indeed possible for tax rulings to violate EU State aid law, a point it had already clarified in the Fiat and Starbucks judgments of September 2019.8 The Commission was thus vindicated on the main issue, but is not ready to throw in the towel just yet. On September 25, 2020, it announced that it would appeal the judgment, arguing that the GC "made a number of errors of law." 9

The present Article goes beyond the media hype, and intends to assess the value of State aid as a tool to fight corporate tax avoidance and harmful tax competition. To do so, it scrutinizes the decisions adopted by the EC, and the outcome of three appeals against this line of decisional practice: those relating to the tax rulings in favor of Fiat in Luxembourg, ${ }^{10}$ Starbucks in the Netherlands, ${ }^{11}$ and Apple in Ireland. ${ }^{12}$ The main argument, and point of departure, is that both the EC and

6. Javier Espinoza et al., EU Refuses to Admit Defeat after Apple Tax Setback, FIN. TIMES (July 16, 2020), https://www.ft.com/content/6cc18c26-04e0-410d-9c0a3f1bafla1685 [https://perma.cc/9QZP-Y858].

7. Ruth Mason, @ ProfRuthMason, TwITTER (July 16, 2020 11:34 AM), https://twitter.com/ProfRuthMason/status/1283787004854009858 [https://perma.cc/S8PG-VH4H].

8. Cases T-755/15 \& T-759/15, Lux. v. Comm'n, ECLI:EU:T:2019:670, para. 45 (Sept. 24, 2019) [hereinafter Fiat Judgment]; Cases T-760/15 \& T-636/16, Neth. v. Comm'n, ECLI:EU:T:2019:669, para. 65 (Sept. 24, 2019) [hereinafter Starbucks Judgment].

9. European Commission, Statement by Executive Vice-President Margrethe Vestager on the Commission's Decision to Appeal the General Court's Judgment on the Apple Tax State Aid Case in Ireland (Sept. 25, 2020), https://ec.europa.eu/commission/presscorner/detail/en/statement_20_1746 [https://perma.cc/9PJ9-LPLY].

10. Fiat Judgment, supra note 8.

11. Starbucks Judgment, supra note 8.

12. Apple Judgment, supra note 1. 
the GC are correct in lending support to the legitimacy of the use of this legal framework to monitor the tax planning practices of multinationals. While adopting legislation might be the optimal approach to solve future issues, State aid presents a unique opportunity to tackle past problematic schemes. In doing so, it affords the EC significant enforcement discretion, and provides a much-needed boost to deterrence in relation to practices of debatable benefits beyond the pockets of the beneficiaries. ${ }^{13}$ The Article thus perceives State aid as a useful weapon to combat tax malpractices, as a complement, not a substitute, of the preferred tax law harmonization strategy.

The Article weighs in on the GC's fairly contentious yet cautious embrace of the arm's length principle ("ALP") for deciding whether an advantage that would not have been obtained under the ordinary tax system has been granted via a tax ruling. Not only did the Commission win on the substance, it also succeeded in pressuring the countries under investigation to change their tax laws so as to prevent the issues it set out to quash in the first place. ${ }^{14}$ Unintendedly, the publicized Commission's losses have further shone a light on the robustness of EU judicial review, and cast doubt on the technology protectionism narrative-the view that EU competition law is being strategically applied against US tech giants so as to favor EU rivals. Despite these positive outcomes, if the State aid route is to be viewed as a long-term strategy, the Commission needs to do its very best to actually triumph. This necessarily entails paying more attention to detail in order to

13. A study of the impact of the tax advantages on the economies of those countries that offer beneficial corporate tax rates is beyond the scope of this study. A common argument is that countries offering tax incentives might foster job creation and thus increase their wealth. The figures in this regard do not necessarily lend support to this view. See, e.g., Cent. Stat. OfF., Household Fin. \& Consumption SURV., INCOME \& WEALTH INFO (2013-2018), https://www.cso.ie/en/releasesandpublications/ep/p-

hfcs/householdfinanceandconsumptionsurvey2018/incomeandwealthinequality/ [https://perma.cc/UAE9-EFKN] (blaming inter alia low wages and weak worker protection on wealth and income inequality). See Elaine Edwards, Irish Inequality Blamed on "Unusually High" Levels of Low Pay and Weak Protections, IRISH TIMES (Feb. 19, 2019), https://www.irishtimes.com/news/social-affairs/irish-inequality-blamed-on-unusuallyhigh-levels-of-low-pay-and-weak-protections-1.3798081] [https://perma.cc/6HMD4X97].

14. See infra Part III.C. 
attempt to meet the evidentiary burden required to tear down the selective advantage brick wall.

To explore these fundamental issues, Part II provides an introduction to State aid rules, a pivotal part of competition law in the European context. Part III discusses tax rulings and the (controversial) tax deals they sometimes endorse. Part IV covers the application of State aid provisions to tax rulings, focusing on the Fiat, Starbucks and Apple cases. Part V critically discusses the adequacy and repercussions of these developments, and the suitability of State aid legislation to tackle detrimental tax competition and tax avoidance. Part VI concludes.

\section{STATE AID AND COMPETITION}

For multinationals, the EC's use of State aid legislation to dismantle their complex corporate tax avoidance systems may have given a whole new meaning to Ronald Reagan's assertion that the most terrifying words in the English language are "I'm from the Government and I'm here to help." 15 To grasp why the "Government help" some of them have been receiving by virtue of tax rulings may be declared unlawful, it is necessary to understand the relevant legal framework. The task here is to provide an understanding of the same. ${ }^{16}$ It is worth noting that, while the scrutiny of tax rulings under State aid law is a relatively new phenomenon, the EC has been relying on these rules to assess certain tax-related issues for decades, despite the fact that the EU has no competence over direct taxation. ${ }^{17}$ Some of the

15. Remarks to Representatives of the Future Farmers of America, 2 PUB. PAPERS 994, 995 (July 28, 1988).

16. Those looking for a comprehensive study of State aid law should consult some of these sources: STATE AID LAW AND BUSINESS TAXATION (Isabelle Richelle et al. eds., Springer 2016); CONOR QUigley, European STATE Aid LAW AND POLICY (Hart Publ'g, 3d ed., 2015); EU STATE AID LAW: EMERGING TRENDS AT THE NATIONAL AND EU LEVEL (Pier L. Parcu et al. eds., Edward Elgar 2020); STATE AID LAW OF THE EUROPEAN UNION (Herwig C. H. Hoffmann et al. eds., Oxford Univ. Press, 2016); ClaIRE MicheaU, STATE AID, SUbSIDY AND TAX INCENTIVES UNDER EU AND WTO LAW (Kluwer Law Int'l, 2014); Eugene Stuart \& IANa Roginska-Green, SiXTy Years of EU STATE AID LAW AND POLICY: ANALYSIS AND ASSESSMENT (Wolters Kluwer, 2018); Lisa Paterno, State Aid and Fiscal Protectionism in the European Union from the Perspective of Competitors, 65 BULL. FOR INT'L TAX'N 343 (2011).

17. LiZA L. GORMSEN, EUROPEAN STATE AID AND TAX Rulings 144 (2019). 
decisional practice and case law in this respect will be discussed where relevant.

\section{A. State Aid Law: a European Affair?}

State aid rules are embedded in the EU's competition law regime, and represent one of its most distinctive features. Unlike in other parts of the world, in Europe it is possible to avert potentially harmful State intervention in the competitive process. This includes not only the concession of State aid, but also certain privileges granted to public undertakings ${ }^{18}$ which may in effect shield them from the competition exerted by the private sector. ${ }^{19}$ In 1994, Claus-Dieter Ehlermann described the "loneliness" of the EC when applying State aid rules: "[t]here are no models and no precedents, there is little academic debate, and the contrast with antitrust is remarkable." ${ }^{20}$ Indeed, there are no equivalent provisions in the United States, where the main antitrust statutes-the Sherman Act of 1890 and the Clayton Act of 1917-focus almost exclusively on joint anticompetitive conduct, harmful monopolistic behavior, and the scrutiny of mergers. ${ }^{21}$

From a competition policy standpoint, the desire to control distortions of competition that are a product of the assistance granted by State entities to firms competing in the marketplace is understandable. Evidently, such aid could furnish those on the receiving end with an unfair competitive advantage over their rivals. ${ }^{22}$ If antitrust is made up of the "laws which make

18. Case C-41/90, Klaus Höfner v. Macrotron GmbH, ECLI:EU:C:1991:161, para. 21 (Apr. 23, 1991) (defining undertakings, subjects of EU competition law, as "entities engaged in an economic activity regardless of their legal status and how they are financed").

19. Consolidated Versions of the Treaty on European Union and the Functioning of the European Union art. 106, May 9, 2008, 2008 O.J. (C 115) 51 [hereinafter TFEU] (art. 106 is the provision applicable to public undertakings).

20. Claus-Dieter Ehlermann, State Aids under European Community Competition Law, 18 FordHAM INT'L L.J. 410, 411 (1994). Note however that in April 2018, the UK Government confirmed its intention to transpose EU state aid legislation into UK law, and therefore the provisions look set to remain relevant and applicable in the UK despite Brexit.

21. Sherman Act, 15 U.S.C. $\$ \S 1-7$ (1890); Clayton Act, 15 U.S.C. $\$ \S 12-27$ (1914).

22. Org. for Econ. Co-operation \& Dev. [OECD], Competition Policy in Subsidies and State Aid, at 7-10 DAFFE/CLP (2001) 24 (Nov. 21, 2001). 
artificial restraints of competition illegal," 23 then arguably State support could restrain other players' ability to compete, and should be controlled. Interestingly, it is also possible to find attempts to curb subsidies in transnational regimes, most notably the World Trade Organization ("WTO"). ${ }^{24}$ In the Uruguay Round of 1994, the General Agreement on Tariffs and Trade ("GATT") 25 established an Agreement on Subsidies and Countervailing Measures applicable to all WTO members. ${ }^{26}$ WTO legislation is binding on the Member States of the EU.27 As a result, the support granted by the EU Member States may be doubly scrutinized, since it must be compatible with both State aid and WTO rules.

The basic EU State aid legislation was introduced in 1957 by the Treaty of Rome, currently referred to as the Treaty on the Functioning of the European Union ("TFEU"). ${ }^{28}$ This Treaty created the European Economic Community-the seed of what we now know as the EU-and triggered an unprecedented process of integration in the Old Continent. Only six countries originally ratified the TFEU (then called the European Economic Community ("EEC") Treaty). Yet the EU has expanded over the years, and currently encompasses twentyseven sovereign nations. State aid rules are inextricably linked to that market-integration objective, and have been considered a fundamental "vehicle for making the completion of the internal

23. Am. Bar Ass'n, Section of Antitrust law, Compliance Manuals for the NEW ANTITRUST ERA 198 (1990).

24. The WTO deals with trade rules between nations. See WORLD Trade OrG. https://www.wto.org [https://perma.cc/NX8W-9Y7E] (last visited Aug. 5, 2020). A discussion of the relevant WTO rules is beyond the scope of this paper. See Roman Grynberg \& Bridget Chilala, WTO Compatibility of the OECD Defensive Measures against Harmful Tax Competition, 2 J. WORLD INV. 507 (2001); MICHEAU, supra note 16; Lucas Bastin, Transfer Pricing and the WTO, 48 J. WORLD TRADE 59 (2014); LUCA RUBINI, THE DEFINITION OF SUBSIDY AND STATE AID: WTO AND EC LAW IN COMPARATIVE PERSPECTIVE (Oxford Univ. Press 2009).

25. General Agreement on Tariffs and Trade, Oct. 30, 1947, 61 Stat. A-11, T.I.A.S. 1700, 55 U.N.T.S. 194 [hereinafter GATT].

26. Agreement on Subsidies and Countervailing Measures, Apr. 15, 1994, Marrakesh Agreement Establishing the World Trade Organization, Annex 1A, 1869 U.N.T.S. $\quad 14, \quad$ https://www.wto.org/english/docs_e/legal_e/24-scm.pdf. [https://perma.cc/PR8U-BS8L] (last visited Oct. 24, 2020).

27. TFEU, supra note 19 , art. 216(2).

28. TFEU, supra note 19. 
market politically acceptable." ${ }^{29}$ Allowing antitrust enforcers to control the anticompetitive effects of State aid may be beneficial for the protection of competition in any given context. However, it is particularly valuable within the policy framework envisioned to assist in the plight to remove obstacles to trade in an economically unified region. These integrationist aspirations that permeate EU competition law justify in part the divergence with the US system. In the words of Helmuth Schröter:

. . . the much broader scope of and plurality of aims pursued by [EU] competition policy result in making antitrust analysis under [Union] law a more complicated process than under the antitrust law of the United States which considers "allocative efficiency/consumer welfare" as the sole valid standard. ${ }^{30}$

State aid may be a regulatory policy, but one "with a difference."31 Since there was practically no Council legislation in the area until the late 1990s, it evolved as a Commission-made strategy. ${ }^{32}$ The EC applied the Treaty provisions in specific investigations, subject to the scrutiny of the European courts. ${ }^{33}$ This distinctiveness is perhaps a recognition that this area is, on the one hand, "crucial for the building and consolidation of the internal market," and on the other hand also "raises extremely sensitive issues for the EU's member states." 34 Moreover, given the wide discretion afforded to the EC, it is arguably "one of the most politicised of the EU's regulatory policies," which allows the EU to take action to intervene when national governments attempt to pursue industrial policies protecting national interests. ${ }^{35}$ An unavoidable consequence is that State aid is an area of tension and conflict, because it "pits the Commission directly against one or more of the member states" in a

29. Andrew Evans \& Stephen Martin, Socially Acceptable Distortions of Competition: Community Policy on State Aid, 16 EUR. L. REv. 79, 110 (1991).

30. Helmuth R. B. Schröter, Antitrust Analysis Under Article 85(1) and (3), in 1987 FORDHAM CORPORATE LAW INSTITUTE 645, 661 (Barry E. Hawk ed., 1988).

31. Michelle Cini, From Soft Law to Hard Law: Discretion and Rule-Making in the Commission's State Aid Regime, 7 (EUI Working Papers, RSC No. 2000/35, 2000).

32. Id.

33. Jan Klabbers, The Undesirability of Soft Law, 67 NORDIC J. INT'L L. 381, 388 (1998); Francis Snyder, Soft Law and Institutional Practice in the European Community, 3 (EUI Working Paper LAW 93/5, 1993).

34. Cini, supra note 31 , at 3.

35. Id. at 8 . 
sovereignty battle. ${ }^{36}$ The recent cases relating to the tax deals of multinationals further show that these tensions can extend beyond the borders of the Union.

It is difficult to compare EU competition law and US antitrust at the best of times, given the different contextual roots, purposes, evolution, ideology and procedure. ${ }^{37}$ However, when it comes to the State aid sphere, it is simply impossible to draw comparisons. Since the raison d'etre of these rules is based on the market integration ambition, they can be a difficult pill to swallow for non-EU firms who might be less sensitive to the importance of a robust internal market. Even within the Union, the application of State aid law frequently leads to jurisdictional tensions, because the measures targeted by the EC are at times embedded in areas considered to be of sole national concern. Needless to say, tax is one of those contentious battlegrounds, as discussed later. 38

\section{B. Competition Concerns}

Aid schemes flourish when crises hit. In the context of the COVID-19 pandemic, governments all over the world have been digging deep into their pockets to prevent companies, even entire industries, from collapse. ${ }^{39}$ And there is very good reason

36. Tim Büthe, The Politics of Competition and Institutional Change in European Union: The First Fifty Years, in THE STATE OF THE EUROPEAN UNION VOL. 8, MAKING History: European InTEgration and Institutional Change at Fifty 186, 189 (Sophie Meunier \& Kathleen R. McNamara eds., 2017).

37. See, e.g., Sandra Marco Colino, The Antitrust "F" Word: Fairness Considerations in Competition Law, J. BUS. L. 329 (2019).

38. See infra Part IV.

39. See, e.g., USDA Announces Coronavirus Food Assistance Program, U.S. DEP'T AGRIC. (Apr. 17, 2020), https://www.usda.gov/media/pressreleases/2020/04/17/usda-announces-coronavirus-food-assistance-program

[https://perma.cc/4ZCZ-PFDB]; Simon Clarke, £20 Million in New Grants to Boost Recovery of Small Businesses, UK MinisTRY HOUSInG, COMMUNITIES \& LOCAL GOv'T (July 30, 2020), https://www.gov.uk/government/news/20-million-in-new-grants-to-boostrecovery-of-small-businesses [https://perma.cc/V5XV-9SRX]; Anti-Epidemic Fund, GOV'T HONG KONG SPECIAL ADMIN. REGION, https://www.coronavirus.gov.hk/eng/anti-epidemic-fund.html

[https://perma.cc/6UPQ-QAZV] (last visited Aug. 5, 2020); Sebastian Lange et al., German Covid-19-Related Grants and Subsidies, DeloITTE (May 5, 2020), https://www2.deloitte.com/dl/en/pages/legal/articles/foerdermoeglichkeitenwirtschaft-covid-19.html [https://perma.cc/3Z7W-35SD]; Morten Bennedsen et al., Understanding the Impact of Government Aid to Firms in the COVID-19 Pandemic, CTR. FOR 
for coming to the rescue. The undesirable social consequences of companies exiting the market, including a higher unemployment rate, may be spared. But even without an economic crunch in sight, incentives might well be required for a myriad of reasons, such as invigorating a specific activity, encouraging firms to adopt environmentally friendly policies, or enabling structural reforms. ${ }^{40}$

Evidently, subsidies may be perfectly compatible with EU State aid law. Even laissez-faire champion Reagan admitted that in some circumstances subsidies are necessary, for instance in cases of "natural disasters like the drought." 41 However, he advocated for a "future where there is less, not more, government in our daily lives," and generally defended that the best way forward was "to get government out of the way" and let competition work its magic. ${ }^{42}$ While his reasoning does not resonate with the logic behind the $\mathrm{EU}$ regime, his bottom line serves to justify the existence of State aid law: there may be undesirable effects on the competitive process derived from supportive State measures, hence the need for legislation with the potential to neutralize those negative outcomes.

The rationale for the inclusion of rules relating to State aid within a system designed to protect competition is straightforwardly explained on the EC's website: "[a] company which receives government support gains an advantage over its competitors. Therefore, the [TFEU] generally prohibits State aid unless it is justified by reasons of general economic development." 43 Since competition law is about ensuring a level playing field, two issues arise in relation to supportive measures. The first is that they could give the recipients an unfair advantage over their competitors. This is more likely to happen when the aid is granted to specific companies rather than an

\footnotetext{
ECON. POL'Y RSCH. (June 18, 2020), https://voxeu.org/article/impact-government-aidfirms-covid-19-pandemic [https://perma.cc/VE6N-5G2C].

40. Sandra Marco Colino, Competition law of the EU and UK (7th ed., Oxford Univ. Press 2019).

41. Remarks to Representatives of the Future Farmers of America, supra note 15, at 995 .

42. $I d$.

43. See State aid control, EUR. http://ec.europa.eu/competition/state_aid/overview/index_en.html [https:/ / perma.cc/9FE4-U8PB] (last visited July 22, 2020).
} 
industry as a whole. Kelyn Bacon explains that, where the edge attained by a company is the fruit of a subsidy instead of a better performance in the market, the integrity of the single market could be affected. Moreover, if a Member State chooses to subsidize a national firm, others may wish to follow suit and offer comparable benefits to their own national companies, thus triggering what Bacon describes as a "subsidy race." 44 The threat to integration of such races meant that state aid was a "political imperative" at the outset of the process. ${ }^{45}$ Nonetheless, this problem is somewhat less pressing nowadays, because the single market is a reality and not all subsidy races have negative consequences. ${ }^{46}$

The second issue relates to economic efficiency, considered the main goal of competition policy. ${ }^{47}$ The effects of state aid on efficiency greatly depend on the circumstances. In some cases, it might be helpful to provide support, particularly in concentrated markets where subsidizing the production of small firms or newcomers may counterbalance the existing market power. At the same time, subsidies may artificially keep unproductive, poorly managed firms in the market, and this would result in inefficiency. From a static perspective, such a situation could crystallize "inefficient industry structures; it may crowd out private investment; it may reduce effective competition by increasing market power or by reducing the

44. Kelyn Bacon, European Union Law of State Aid 9 (3d ed., Oxford Univ. Press 2017); James Langenfeld \& Christopher Alexander, State Aid and Supply-Side Geographic Market Definition, 12 EUR. STATE AID L. Q. 362, 362 (2013).

45. BACON, supra note 44 , at 9.

46. $I d$.

47. According to the OECD, "[t]here is general consensus that the basic objective of competition policy is to protect and preserve competition as the most appropriate means of ensuring the efficient allocation of resources-and thus efficient market outcomes—in free market economies." Org. for Econ. Co-operation \& Dev. [OECD], Interim Report on Convergence of Competition Policies, at para. 4, OECD/GD (94) 64 (June 1994). There is extensive literature on this topic. See, e.g., Valentine Korah, EEC Competition Policy—Legal Form or Economic Efficiency?, 39 CURRENT LEGAL Problems 85 (1986); Gregory T. Gundlach \& Diana Moss, The Role of Efficiencies in Antitrust Law: Introduction and Overview, 60 ANTITRUST BULL. 91 (2015); Kenneth G. Elzinga, The Goals of Antitrust: Other than Competition and Efficiency, What Else Counts?, 125 U. PA. L. REV. 1191 (1977); Ioannis Lianos, Competition Law for a Complex Economy, 50 INT'L REV. InTELl. Prop. \& COMPETITION L. 643 (2019); Pieter Kalbfleisch, Aiming for Consumer Alliance: Competition Law and Consumer Welfare, 2 J. EuR. COMPETITION L. \& PRAC. 108 (2011). 
incentives to compete; it may distort production and location decisions across Member States; and it may foster overly risky or otherwise inefficient behaviour." 48 And from a dynamic perspective, it could also "help perpetuate failed business models, reduce incentive to compete, and create moral hazard by encouraging excessive risk-taking." 49

It follows from the above that State aid is not always detrimental, but does require close monitoring to curb its potential harmful effects on competition and, in the European context, on integration. This imposes on the EC the arduous task of weeding out potentially harmful aid from the (majority of) beneficial support. There are frequent disagreements between the EC and the European courts as to what constitutes unlawful aid. While originally the application of State aid rules focused mainly on avoiding distortions within the EU, and dealing with the risks of protectionism (particularly of national champions) for the creation of a single market, this is currently less pressing. Now that it has been able to move beyond the market integration imperative, the EC has begun looking at a broader range of measures. That is how the State aid road eventually led to the scrutiny tax rulings, a pivotal pursuit nowadays. ${ }^{50}$

\section{The EU Rules on State Aid}

In the early days of the EEC, the Commission had to devote its (limited) resources to chiseling its general competition policy. It focused mainly on its approach to joint anticompetitive conduct, and to a lesser extent on single-firm abusive practices. It was in the mid 1980s, almost three decades after the Treaty of Rome was signed, when it could afford to look towards the application of State aid rules. Since then, State aid policy has blossomed. There is currently a specialized section within DG Comp-Directorate $\mathrm{H}$, composed of six units-which deals with State aid cases. The Deputy Director-General for State aid is

48. BACON, supra note 44 , at 10.

49. Id. at 11.

50. See infra Part IV. 
Carles Esteva Mosso, an experienced Commission official with a background in law, economics and political science. ${ }^{51}$

\section{General Legal Framework}

The main Treaty provisions on State aid can be found in Articles 107 to 109 TFEU. Article 107(1) is of vital importance, and contains a blanket prohibition of aid favoring specific companies (or "undertakings" in EU terminology) ${ }^{52}$ unless they fall into a particular exception. Article 108 TFEU compels the EC to keep all systems of aid "under constant review," and to do so in cooperation with the Member States. ${ }^{53}$ The EC can eliminate or modify the aid it considers problematic, ${ }^{54}$ and has the power to adopt block exemptions. ${ }^{55}$ In exceptional circumstances, the Council may, at the request of a Member State, declare illegal aid as being lawful, always subject to judicial review. 56 The Member States must inform the Commission if they plan to grant or alter aid. ${ }^{57}$ Article 109 TFEU enables the Council: (1) to adopt the regulations required for the application of 107 and 108; (2) to determine the categories of aid that may be lawful; and (3) to define the conditions for legality. ${ }^{58}$

These rules are accompanied by a body of extensive secondary legislation and soft law which expands the legal principles applicable to the scrutiny of aid. ${ }^{59}$ Among them are

51. Directorate General for Competition, Eur. COMM'N (Jan. 10, 2020), https://ec.europa.eu/dgs/competition/directory/organi_en.pdf [https://perma.cc/PY7H-7U24].

52. According to the CJ, "the concept of an undertaking encompasses every entity engaged in an economic activity, regardless of the legal status of the entity and the way in which it is financed." Case C-41/90, Klaus Höfner and Fritz Elser v. Macrotron GmbH, ECLI:EU:C:1991:161, para. 21 (Apr. 23, 1991).

53. TFEU, supra note 19, art. 108.

54. Id. art. $108(2)$.

55. Id. art. 108(4). Block exemptions are pieces of EU legislation which "automatically bring certain categories of conduct within the terms of [the TFEU], preventing the need to conduct case-by-case analysis" (in this case of specific aid granted). MARCO COLINO, supra note 40, at 253.

56. TFEU, supra note 19, art. 108(2).

57. Id. art. 108(3).

58. Id. art. 109.

59. Secondary legislation is enacted by the EU institutions to develop the "principles and objectives set out in the treaties". See EU Law, EUR. UNION, 
Regulation 2015/1589 (on procedure), ${ }^{60}$ Regulation 615/2014 (the block exemption), ${ }^{61}$ and the Notion of State Aid Notice. ${ }^{6}$ This Notice provides valuable guidance for the application of Article 107 to tax rulings. The provisions that make up the State aid legal framework legislation are "riddled with exceptions which attempt to strike a balance between the protection of competition on the one hand, and the right of the Member States to act in defence of a wide range of legitimate interests on the other." 63

\section{The Prohibition of Article 107(1) TFEU}

The fundamental EU State aid provision can be found in Article 107(1) TFEU:

Save as otherwise provided in this Treaty, any aid granted by a Member State or through State resources in any form whatsoever which distorts or threatens to distort competition by favouring certain undertakings or the production of certain goods shall, insofar as it affects trade between Member States, be incompatible with the internal market.

In the Altmark case, ${ }^{64}$ the Court of Justice ("CJ") referenced four conditions required for the application of this prohibition:

First, there must be an intervention by the State or through State resources. Second, the intervention must be liable to affect trade between Member States. Third, it must confer an advantage on the recipient. Fourth, it must distort or threaten to distort competition. ${ }^{65}$

https://europa.eu/european-union/law_en [https://perma.cc/H2JD-ZGHN] (last visited Aug. 5, 2020).

60. Council Regulation 2015/1589 of 13 July 2015 Laying Down Detailed Rules for the Application of Article 108 of the Treaty on the Functioning of the European Union, 2015 O.J. (L 248) 9, 9.

61. Commission Regulation 615/2014 of 17 June 2014, Declaring Certain Categories of Aid Compatible with the Internal Market in Application of Articles 107 and 108 of the Treaty on the Functioning of the European Union, 2014 O.J. (L 187) 1.

62. Commission Notice on the Notion of State Aid as Referred to in Article 107(1)

of the Treaty on the Functioning of the European Union, 2016 O.J. (C 262) 1.

63. MARCo COLINO, supra note 40, at 495 .

64. Case C-280/00, Altmark Trans GmbH v. Regierungspräsidium Magdeburg, 2003 E.C.R. I-7810.

65. Id. at I-7836. 
An additional requisite recognized by the EU judiciary is that the advantage conferred must be selective. According to the CJ, "the requirement as to selectivity under $107(1)$ must be clearly distinguished from the concomitant detection of an economic advantage." 66 However, in practice selectivity is often analyzed "as a dimension of the advantage criterion." 67 These requirements need to be interpreted taking into account the Notion of State Aid Notice, ${ }^{68}$ and the relevant case law. They are discussed below.

\section{a. "Intervention by the State or through State Resources"}

According to the Notion of State Aid Notice, for aid to be of State origin it must be both granted directly or indirectly through State resources, and imputable to the State. ${ }^{69}$ With regard to the first condition, the financial burden of the advantage gained ought to be borne by the State. ${ }^{70}$ The term "State" here is subject to a broad interpretation, and comprises intra-state entities ${ }^{71}$ or public undertakings. ${ }^{72}$ In principle, this would mean that measures funded by private companies fall outside the scope of the prohibition. ${ }^{73}$ Yet there are situations in which the EU judiciary has recognized that the resources of private bodies might be problematic, for instance where the private funds are managed under the instructions of a government, ${ }^{74}$ and "they constantly remain under public control and therefore available to the competent national authorities." 75

66. Case C-15/14, Comm'n v. MOL Magyar Olaj-és Gázipari Nyrt, ECLI:EU:C:2015:32, para. 59 (Jan. 22, 2015). In this sense, Ruth Mason considers selectivity as a fifth condition for the application of Article 107(1) TFEU. See Ruth Mason, Tax Rulings as State Aid FAQ, 154 TAX NOTES 451, 452 (Jan. 23, 2017).

67. Wolf Sauter, The Criterion of Advantage in State Aid: Altmark and Services of General Economic Interest, in TILEC DISCUSSION PAPER NO. 2014-05 1, 2 (2014).

68. See Council Regulation 2015/1589, supra note 60.

69. Id. para. 38.

70. MARCO COLINO, supra note 40.

71. Examples include regional and federal bodies.

72. MARCO COLINO, supra note 40.

73. Case C-379/98, PreussenElektra v. Schleswag AG, 2001 E.C.R. I-2159.

74. See, e.g., Case C-206/06, Essent Netwerk Noord BV v. Aluminium Delfzijl BV, 2008 E.C.R. I-5497 case C-206/06 [2008] 3 CMLR 32; Case T-47/15, Germany v. Comm'n, ECLI:EU:T:2016:281 (May 10, 2016).

75. Case C-262/12, Ass'n Vent de Colère! Fédération Nationale v. Ministre de 1 Écologie, ECLI:EU:C:2013:851, para. 21 (Dec. 19, 2013). 
The EC's view, as explained in the Notion of State Aid Notice, is that "the origin of the resources is not relevant provided that, before being directly or indirectly transferred to the beneficiaries, they come under public control and are therefore available to the national authorities, even if the resources do not become the property of the public authority." 76 However, the Notice is not binding, and it is not yet clear the extent to which the European courts will support this very broad interpretation.

It is important to note that those state resources have to be transferred, that is, the public funds must be handed over to a company. ${ }^{77}$ But the concept of transfer also encompasses "waiv[ing] revenue which would otherwise have been paid to the Treasury."78 It does not catch assurances of support, if these never materialize..$^{79}$ The Notion of State Aid Notice explains that:

The transfer of State resources may take many forms, such as direct grants, loans, guarantees, direct investment in the capital of companies and benefits in kind. A firm and concrete commitment to make State resources available at a later point in time is also considered a transfer of State resources. A positive transfer of funds does not have to occur; foregoing State revenue is sufficient. Waiving revenue which would otherwise have been paid to the State constitutes a transfer of State resources. For example, a "shortfall" in tax and social security revenue due to exemptions or reductions in taxes or social security contributions granted by the Member State, or exemptions from the obligation to pay fines or other pecuniary penalties, fulfils the State resources requirement of Article 107(1) [TFEU]. The creation of a concrete risk of imposing an additional burden on the State in the future, by a guarantee or by a contractual offer, is sufficient for the purposes of Article 107(1). ${ }^{80}$

\footnotetext{
76. Commission Notice on the Notion of State Aid, supra note 62, para. 57 .

77. MARCO COLINO, supra note 40.

78. Case T-67/94, Ladbroke Racing Ltd. v. Comm'n, 1998 E.C.R II-1, para. II-45.

79. Case C-81/10, France Télécom SA v. Comm'n, ECLI:EU:C:2011:811 (Dec. 8,

80. Commission Notice on the Notion of State Aid, supra note 62, para. 51.
} 2011). 
The second requirement, State imputability, was laid down by the CJ in the Stardust Marine case..$^{81}$ It does not necessarily require demonstrating that a public authority instructed a company to adopt a measure, and in some cases this might be inferred from the circumstances. According to the Notion of State Aid Notice, aid is imputable to the state where a public authority grants some kind of advantage, or where it designates a body to administer a measure giving an advantage. When the aid is provided by a public undertaking which grants, the degree to which public authorities were behind the adoption of the measure needs to be determined. ${ }^{82}$ Moreover, the decision to grant aid must be unilateral and autonomous. ${ }^{83}$ This implies that a measure will not be imputable to the state if it is merely complying with "obligations stemming from the Treaty," unless there is some discretion. ${ }^{84}$

\section{b. "Liable to Affect Trade Between Member States"}

In line with the TFEU's other competition law provisions, Article 107 only applies where there is an effect on trade between the countries that form part of the Union. 85 The logic behind this constraint is purely jurisdictional. The EU can only act in those areas where it is empowered to do so by the Treaty, and everything else remains governed by the national laws of its members. ${ }^{86}$ Given that the main aim of the Treaty is to foster economic integration, the European institutions have powers to act in those areas that can affect the proper functioning of the internal market. As explained in the Hugin case:

[Union] law covers any agreement or any practice which is capable of constituting a threat to freedom of trade between Member States in a manner which might harm the attainment of the objectives of a single market between the Member Estates, in particular by partitioning the national markets or by affecting the structure of competition within

81. Case C-482/99, France v. Comm'n (Stardust Marine Case), ECLI:EU:C:2002:294 (May 16, 2002).

82. Commission Notice on the Notion of State Aid, supra note 62, paras. 39-40.

83. Case T-351/02, Deutsche Bahn AG v. Comm'n, ECLI:EU:T:2006:104, paras. 2, 100.

84. Id. para. 102.

85. TFEU, supra note 19 , art. 107.

86. Case C-22/78, Hugin Kassaregister AB v. Comm'n, 1979 E.C.R 1870, 1870. 
the [Internal] Market. On the other hand conduct the effects of which are confined to the territory of a single Member State is governed by the national legal order. ${ }^{87}$

In State aid, the determining factor is whether the support potentially ${ }^{88}$ bolsters the position of an undertaking vis-à-vis its competitors when it comes to trading within the EU. ${ }^{89}$ Since all that is required is that the aid is liable to affect trade and distort competition, ${ }^{90}$ this condition can be met even if the beneficiaries do not export goods or services. Their size and the amount of aid granted are irrelevant, as long as the chance to penetrate national markets is reduced..$^{91}$

\section{c. "Distort or Threaten to Distort Competition"}

"[I]nextricably linked" to the effect on trade between the Member States is the notion of restriction of competition, ${ }^{92}$ and the assessment of the two requirements usually goes hand in hand. Both the TFEU and the Notion of State Aid Notice specify that potential threats to competition may be caught. All that is required is that the aid be "liable to improve the competitive position of the recipient compared to other undertakings with which it competes."93

\section{d. "Confer a [Selective] Advantage"}

Indisputably, the most contested element of the prohibition contained in Article 107(1) TFEU is the requirement that the aid must favor specific undertakings. The case law and decisional practice of the EC have clarified that the aid must constitute an advantage, and that advantage must be conferred displaying a degree of selectivity. ${ }^{94}$ This Section assesses these

87. Id.

88. An actual effect is not required. See Case C-280/00, Altmark Trans GmbH v. Regierungspräsidium Magdeburg, 2003 E.C.R. I-7810; Case C-518/13, Eventech Ltd. v. The Parking Adjudicator, ECLI:EU:C:2015:9 (Jan. 14, 2015); Joined Cases C-197/11 \& C-203/11, Libert v. Gouvernement Flamand, ECLI:EU:C:2013:288 (May 8, 2013) [hereinafter Libert].

89. Case T-298/97, Mauro v. Comm'n, 2000 E.C.R. II-2325.

90. Libert, supra note 88 , para. 48.

91. Id. para. 78.

92. Commission Notice on the Notion of State Aid, supra note 62, para. 186.

93. Id. para. 187.

94. MARCO COLINO, supra note 40. 
two complex yet fundamental requisites. Perhaps the best way to explain the difference between advantage and selectivity is to note that to assess the former it is necessary to compare the aid under scrutiny with the usual treatment given in similar situations, whereas for the latter it is the actual treatment that Member States grant other undertakings in a comparable situation that is relevant. ${ }^{95}$

The EC tends to look at whether "the recipient undertaking receives an economic advantage which it would not have obtained under normal market conditions." 96 The key issue is thus whether the aid places the undertaking in a position it would not have had achieved had it been subject to competition in the market. This parameter casts a very wide net, and requires an analysis of the counterfactual, that is, of the recipient's position in the absence of the aid. The most obvious measures would be positive benefits, or actual transfers of funds. However, reducing certain economic burdens, thereby mitigating "the charges which are normally included in the budget of an undertaking" has a similar effect. ${ }^{97}$ This second category is relevant for the tax rulings discussed in this Article. In this regard, the $\mathrm{CJ}$ has confirmed that a tax exemption which "places the persons to whom it applies in a more favourable financial situation than other taxpayers" may be problematic. ${ }^{98}$

The general principles for assessing the existence of an advantage have been developed by the EU judiciary and are summarized in the Notion of State Aid Notice. ${ }^{99}$ In public investment matters, the market economy investor principle ("MEIP"), or market investor test, is particularly important. ${ }^{100}$

95. José Luis Buendía, Are Tax Rulings Selective, TAX \& STATE AID IBC CONF. (2016), https://slideplayer.com/slide/14123071/ [https://perma.cc/35HD-GYWE] (last visited Aug. 5, 2020). See also Alfonso Lamadrid, Fiscal State Aid in Court: Recent

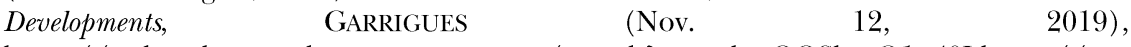
https://webcache.googleusercontent.com/search?q=cache:QQSkusO1u40J:https://ant itrustlair.files.wordpress.com/2019/11/fiscal-state-aid-in-court-

a.lamadrid.pptx $+\& \mathrm{~cd}=2 \& \mathrm{chl}=\mathrm{en} \& \mathrm{ct}=\mathrm{clnk} \& \mathrm{gl}=\mathrm{us}[\mathrm{https} / / /$ perma.cc $/ \mathrm{FB} 9 \mathrm{M}-\mathrm{WNTR}]$.

96. Case C-39-94, SFEI v. La Poste, 1996 E.C.R. I-3577, I-3596.

97. Case C-143/99, Adria-Wien Pipeline $\mathrm{GmbH}$ v. Finanzlandesdirektion für Kärnten, 2001 E.C.R. I-8384.

98. Joined Cases C-106/09 P \& C-107/09 P, Comm'n v. Gov't of Gibraltar, 2011 I11113 , para. 72.

99. Commission Notice on the Notion of State Aid, supra note $62, \S 4$. 100. MARCO COLINO, supra note 40. 
According to the MEIP, an investment will not amount to State aid when it would be acceptable to a private investor under normal market economy conditions. ${ }^{101}$

For Article $107(1)$ to kick in, it is further necessary that "certain undertakings or categories of undertakings or... certain economic sectors" are advantaged "in a selective way." 102 Selectivity entails a differentiated treatment, and may occur even if the measure applies to all undertakings, or to an unlimited number of undertakings chosen on the basis of objective criteria. ${ }^{103}$ Neither the number of recipients, nor the diversity and size of the sectors to which they belong can exclude selectivity "if not all economic sectors can benefit" from said measure. ${ }^{104}$ The crucial issue is that the measure in question favors "certain undertakings... in comparison with other undertakings which are in a legal and factual situation which is comparable in the light of the objective pursued," provided there is no justification. ${ }^{105}$

In some cases, legal criteria may determine that a measure is reserved for specific beneficiaries. When that happens, selectivity is de jure and is easy to prove. However, there are also scenarios in which objective criteria in fact benefit certain companies. ${ }^{106}$ This is known as de facto selectivity, and happens inter alia when public authorities have discretion over general rules. ${ }^{107}$ The CJ refers to a three-step selectivity analysis. The first step is to identify a framework of reference. The second step involves determining whether the measure is a derogation from that framework. The third and final step requires analyzing whether the measure might be justified by the nature or the general scheme of the reference system (in which case it would

101. Commission Common Position (EC) No. 9-1984, 93.

102. Commission Notice on the Notion of State Aid, supra note 62, para. 117 (emphasis added).

103. Id. para. 118.

104. Id.

105. Case C143-99, Adria-Wien Pipeline GmbH v. Finanzlandesdirektion für Kärnten, 2001 E.C.R. I-8384, para 41. This is the definition of material selectivity. This is opposed to regional selectivity, which favors certain regions within a country. An analysis of the latter is beyond the scope of this paper.

106. Commission Notice on the Notion of State Aid, supra note 62, para. 121.

107. Case C-241/94, France v. Comm'n, 1996 E.C.R. I-4551, 1 C.M.L.R. 98, para. 18 (1997) 
be lawful). ${ }^{108}$ These principles have been relied upon by the EC in the decisions relating to tax rulings, and are therefore particularly relevant for the purposes of this Article. ${ }^{109}$

Exactly what constitutes selectivity in fiscal measures has been subject to some debate. For instance, the EC and the GC have defended the legality of tax exemptions intended to encourage the use of non-renewables, ${ }^{110}$ but the CJ disagreed, ${ }^{111}$ insisting that it is the effects and not the objectives that matter. ${ }^{112}$ More recently, in 2015 the $\mathrm{CJ}$ confirmed a Commission decision that had been annulled by the GC relating to tax deductions given to Spanish companies on the goodwill from their shareholdings in foreign companies. ${ }^{113}$ The conditions for the deductions were selective, according to the $\mathrm{EC}$, since they amounted to a derogation from the corporate tax rules applicable to all Spanish corporations. The effect of the system was that companies investing in overseas companies received an advantageous treatment. The GG focused on the required criteria, and since these could potentially be met by every company, it found the scheme to be lawful. ${ }^{114}$ However, for the CJ, the key issue was the effect of acquiring shareholdings in foreign, as opposed to national, companies. ${ }^{115}$ In its view, selectivity ought to be assessed by considering whether the aid "introduces, between operators that are, in the light of the objective pursued by the general tax system concerned, in a comparable factual and legal situation, a distinction that is not

108. Joined Cases C-78/08 to 80/08, Paint Graphos v. Ministero dell'Economia e delle Finanze, 2011 E.C.R. I-7611, para. 65.

109. See infra Part IV.

110. Case T-210/02, British Aggregates Ass'n v. Comm'n, 2006 E.C.R. II-2789, para. 61.

111. Case C-487/06, British Aggregates Ass'n v. Comm'n, 2 C.M.L.R. 10, paras. $85-86(2008)$.

112. In a similar vein, a corporate tax reform which in effect favors offshore companies constitutes illegal State aid. See Joined Cases C-106 \& 107/09 P, Comm'n v. Gov't of Gibraltar, 2011 E.C.R. I-11113, paras. 107-108 (setting aside the judgment of the GC, joined cases T-211 \& 215/04, 2008 E.C.R. II-3745).

113. Case T-219/10, Autogrill España, SA v. Comm'n, ECLI:EU:T:2014:939, para. 90 (Nov. 7, 2014) [hereinafter Autogrill España]; Case T-399/11, Banco Santander SA v. Comm'n, ECLI:EU:T:2014:938, paras. 92-93 (Apr. 11, 2014).

114. Autogrill España, supra note 98, paras. 61-62.

115. Joined Cases C-20/15 P \& 21/15 P, Comm'n v. World Duty Free Group SA, ECLI:EU:C:2016:981, para. 68 (Dec. 21, 2016). 
justified by the nature and general structure of that system."116 It requires a derogation from the ordinary tax system which in effect leads to a differentiated treatment of operators, regardless of whether the operators which meet the conditions are in a "comparable factual and legal situation" to the rest. ${ }^{117}$

Another recent disagreement between the GC and the CJ related to the legality of the Spanish Tax Lease System, a tax relief scheme coordinated by banks for shipping companies that purchased ships from Spanish shipyards. In fact, the direct beneficiaries were Economic Interest Groups ("EIGs") that acted as intermediaries for their members, who ultimately received the tax benefits. The $\mathrm{EC}$ found the system to be selective, because the relief only applied to designated investments and only in ships. For the GC, since ultimately the investors benefitted from the advantages, and all operators purchasing vessels could be eligible, the system was not selective. ${ }^{118}$ However, the CJ confirmed that the concept of State aid does not depend on the legal status of the undertakings nor the techniques used to grant the benefits. ${ }^{119}$ The advantages may have been transferred to the members of the EIGs, but the EIGs themselves were the direct beneficiaries.

The above reflection reveals that some bright lines have already been drawn by the European courts when it comes to assessing the existence of a selective advantage. In practice however, its presence largely depends upon case-specific nuances. As a consequence, venturing to predict the outcome of a case is an inherently risky endeavor, as the GC's tax rulings judgments reiterate. ${ }^{120}$

116. $I d$. para. 60 .

117. Id. para. 67.

118. Joined Cases T-515/13 \& 719/13, Spain v. Comm'n, ECLI:EU:T:2015:1004, para. 148 (Dec. 17,2015 ).

119. Case C-128/16 P, Comm'n v. Spain and Others, ECLI:EU:C:2018:591, para. 46 (July 25, 2018).

120. See infra Part IV. 


\section{TAX RULINGS AND THE TAX DEALS OF MULTINATIONAL COMPANIES}

\section{A. Understanding Tax Rulings}

The EC defines tax rulings as "comfort letters issued by tax authorities to give a company clarity on how its corporate tax will be calculated or on the use of special tax provisions."121 They are also known as advance pricing arrangements ("APAs"), since they amount to binding administrative decisions on the tax applicable to transactions which have yet to be carried out. This anticipated character is the reason why Leslie Wayne $e t$ al. have fittingly described APAs as being "like taking your tax plan to the government and getting it blessed ahead of time."122 Tax rulings originated in the United States, and have been embraced by the Organization for Economic Co-operation and Development ("OECD") and its members. ${ }^{123}$ They have thus become commonplace around the world and, as the EC itself recognizes, need not constitute State aid. They may be perfectly lawful, and are frequently used by companies needing to allocate profits across various jurisdictions in order to predict how their intra-group transactions will be taxed. ${ }^{124}$

There is no standard format for APAs. They are individually tailored for each company and are subject to significant variations, making the concept somewhat of a hodgepodge. As Liza Lovdahl Gormsen explains, the concept catches a "wide range of administrative instruments that aim at certainty, each with their own rules" which can be understood in the context of

121. European Commission Press Release IP/15/5880, Commission decides selective tax advantages for Fiat in Luxembourg and Starbucks in the Netherlands are illegal under EU state aid rules (Oct. 21, 2015), https://ec.europa.eu/commission/presscorner/detail/en/IP_15_5880 [https://perma.cc/XY9H-BKT2] (last visited Aug. 5, 2020).

122. Leslie Wayne et al., Leaked Documents Expose Global Companies' Secret Tax Deals in Luxembourg, INT'L CONSORTIUM OF INVESTIGATIVE JOURNALISM (Nov. 5, 2014).

123. See, e.g., OECD, Harmful Tax Practices - 2017 PeEr ReVIEW Reports on THE EXCHANGE OF INFORMATION ON TAX RULINGS (Dec. 13, 2018), https://www.oecd.org/tax/beps/harmful-tax-practices-2017-peer-review-reports-on-theexchange-of-information-on-tax-rulings-9789264309586-en.htm [https://perma.cc/HGK9-JQX8].

124. See Theorodos Iliopoulos, The State Aid Cases of Starbucks and Fiat: New Routes for the Concept of Selectivity?, 16 EUR. STATE AID L. Q. 263, 265 (2017). 
"avoiding disputes and preventing genuine double taxation."125 Indeed, legal certainty lies at the heart of their adoption. ${ }^{126}$ There is a persuasive logic in the argument that uncertain tax policies discourage investment, ${ }^{127}$ because they can become risky and thus undesirable. ${ }^{28}$ Yet the importance of certainty may be overrated, and the idea that risk can be entirely removed is at best naïve. ${ }^{129}$ While tax matters are the exclusive competence of each country's tax administrations, and theoretically they have the power to consent to even flagrant tax elusion strategies, there are certain limitations to their discretion. Overlooking that APAs may run counter to the EU's State aid rules serves to illustrate that the sense of certainty these arrangements provide is far from bulletproof. 130

\section{B. The Tax Arrangements of Multinational Enterprises}

To understand why tax rulings might be problematic, it is necessary to understand the kinds of tax schemes they often sanction. The above description of APAs, ${ }^{131}$ as instruments providing tax certainty for companies needing to distribute profits across countries, accurately suggests that these arrangements will be particularly valuable for multinational enterprises ("MNEs") who have dealings in several jurisdictions. As the International Monetary Fund ("IMF") has acknowledged, MNEs have at their disposal "many devices-often highly complex, interlocking, and very effective-by which to reduce

125. GORMSEN, supra note 17 , at 1 .

126. The Notion of State Aid Notice states that tax rulings are offered "[f]or reasons of legal certainty." Commission Notice on the Notion of State Aid, supra note 62, para. 169. In a similar vein, Diller et al. define them as "instruments that offer legal certainty on a specific tax issue associates with a future business activity". See Markus Diller et al., Boone or Bane? Advanced Tax Rulings as a Measure to Mitigate Uncertainty and Foster Investment, 26 EUR. ACCT. REV. 441, 442 (2017). See also Iliopoulos, supra note 124, at 264.

127. See Diller, supra note 126; Rainer Niemann, The Impact of Tax Uncertainty on Irreversible Investment, 5 REV. OF MANAGERIAL SCI. 1, 1 (2011).

128. James Alm, Uncertain Tax Policies, Individual Behavior, and Welfare, 78 AM. ECON. REV. 237, 237 (1998).

129. For a discussion of the relative value of legal certainty, see Isabel LifanteVidal, Is Legal Certainty a Formal Value?, JURIS. (2020).

130. See infra Part V.A.3.

131. See supra Part III.A. 
their total tax bills." 132 In this Subsection, the complex setups of corporations branched out over multiple jurisdictions (the usual beneficiaries of APAs) are discussed.

\section{The Risks of Transfer (mis)Pricing}

Transactions within MNEs account for more than 60 percent of global trade. Taxing these operations correctly is therefore a crucial endeavor for any economy. ${ }^{133}$ The process of allocating profits (mainly for tax purposes, but also for other matters) between the different branches or parts of MNEs is known as transfer pricing. ${ }^{134}$ John Neighbour provides an illustrative example of the concept:

Consider a profitable UK computer group that buys microchips from its own subsidiary in Korea: how much the UK parent pays its subsidiary-the transfer price-will determine how much profit the Korean unit reports and how much local tax it pays. ${ }^{135}$

Among the perks of globalization for the business community is the possibility to "shop around" for lenient tax laws, thereby significantly reducing their tax bills. ${ }^{136}$ One obvious temptation is to use transfer pricing to allocate a big portion of

132. IMF, Spillovers in International Corporate Taxation, IMF Policy Paper 8 (May 9, 2014).

133. John Neighbour, Transfer Pricing: Keeping It at Arm's Length, OECD OBSERVER
No. https://oecdobserver.org/news/archivestory.php/aid/670/Transfer_pricing:_Keeping _it_at_arms_length.html [https://perma.cc/3W4H-XFH4].

134. See, e.g., Elizabeth King, Transfer Pricing and Corporate TaXation (Springer 2008); INT'L BurEaU OF FisCAL DOCuMENTATION, TRANSFER Pricing AND INTRA-GROUP FINANCING (Anuschka Bakker \& Marc M. Levey eds., 2012); ROBERT FEINSCHREIbER \& MARGARET Kent, TRANSFER PRICING HANDBOOK: GUIDANCE FOR OECD REgulations (Wiley 2012); Fundamentals of InTERnATIONAL Transfer PRICING IN LAW AND ECONOMICS (Wolfgang Schön \& Kai A. Konrad eds., 2012).

135. Neighbour, supra note 133.

136. Mike Collins, The Pros and Cons of Globalization, FORBES (May 6, 2015), https://www.forbes.com/sites/mikecollins/2015/05/06/the-pros-and-cons-ofglobalization/\#2de6bbaccee0 [https://perma.cc/4FBF-CGNZ]. The OECD worries that it is possible to "associate more profits with legal constructs and intangible rights and obligations, and to legally shift risk intra-group, with the result of reducing the share of profits associated with substantive operation." OECD, ADDRESSING BASE Erosion And Profit ShIFTING 33 (2013). See also Thomas Pearson, Proposed International Legal Reform for Reducing Transfer Pricing Manipulation of Intellectual Property, 40 N.Y.U. J. INT'L L. \& POL. 541, 548 (2008). 
the profits to jurisdictions with low tax rates. ${ }^{137}$ This would lead to what Shane Darcy calls transfer mispricing, ${ }^{138}$ and it is one of the principal reasons why Ireland, the Netherlands or Luxembourg are attractive for multinationals. For instance, the Irish corporate tax rate is twelve and a half percent, while in the United States it is twenty-one percent. Companies are thus drawn to engage in what is known as corporate or tax inversion, which implies transferring stocks or assets to a foreign corporation "to reduce tax and regulatory costs." 139 According to the EC, the temptation to assign reduced profits to high tax jurisdictions "could lead to exaggerated transfer prices which should not be accepted as a basis for calculating taxable income." 140

Manipulating profit allocation is particularly straightforward for firms whose main source of income stems from intangible property, such as intellectual property ("IP") rights. ${ }^{141}$ This explains why big tech and pharmaceutical companies are frequently the beneficiaries of the strategies hereby described. Thomas Pearson explains, for instance, that:

MNE Groups often attribute research and development (R\&D) expenses to higher-tax countries which provide immediate expensing of these R\&D costs. However, in reality, the R\&D costs of producing IP may be widely dispersed among related entities. Subsequent transfer prices charged through royalty fees to affiliate MNEs often fail to adequately adjust for the real risk premium assumed in the original development of the IP. ${ }^{142}$

137. Boyu Wang, After the European Commission Ordered Apple to Pay back Taxes to Ireland: Ireland's Future in the New Global Tax Environment, 28 IND. J. GLOBAL LEGAL STUD. 539, 543 (2016).

138. Shane Darcy, "The Elephant in the Room": Corporate Tax Avoidance E Business and Human Rights, 2 BUS. \& HUM. RTS. J. 1, 4 (2017).

139. Luyang Liu, Is American Multinational Enterprises' Honeymoon with the European Union Over? An Analysis of the European Commission's Investigations into American Multinational Enterprises' Tax Deals with Ireland, Luxembourg and the Netherlands, 41 LoY. L.A. INT'L \& COMP. L. REV. 71, 72 (2018).

140. Commission Decision (EU) 2016/2326 of 21 October 2015 on State aid which Luxembourg granted to Fiat, 2016 O.J. (L 351) 1, 16 [hereinafter Fiat Decision].

141. Steven A. Bank, The Globalization of Corporate Tax Reform, 40 PEPP. L. REV. 1307,1307 (2013).

142. Pearson also explains that weak financial accounting further helps hide transfer pricing abuses. Pearson, supra note 136, at 563 . 
But the tax tactics of some multinationals are not simply designed to obtain a better tax deal. These companies sometimes profit from legal lacunae and misalignments between the tax systems of different countries to elude taxes. The "arrangements exploiting differences in the tax treatment of instruments, entities or transfers between two or more entities" are known as hybrid mismatches. ${ }^{143}$ They can be used for domestic tax base erosion and profit shifting ("BEPS"), defined by the OECD as "tax planning strategies used by multinational enterprises that exploit [hybrid mismatches] to avoid paying tax." 144 A classic example would be the so-called "double Irish sandwich" arrangements, infamously used by companies such as Apple or Google. ${ }^{145}$

What did it take to prepare a double Irish sandwich? The essential ingredients included: (1) the low corporate tax rates of some EU Member States; (2) the further rate reductions available in Europe on certain IP-related income; (3) bilateral agreements preventing double taxation entered into by the United States and the relevant European countries; (4) some tax havens, like Bermuda, and (5) a legal loophole, namely the mismatch in tax residence rules between the corporate tax laws of the United States and Ireland. ${ }^{146}$ Luyang Liu provides a very accurate recipe:

The first step is for the US corporation ("US Co") to transfer some intangible property rights ... to an Irish subsidiary ("IR Co A") that is incorporated in Ireland but has its headquarters located in Bermuda or other tax havens with no income tax. This company is not designed like this by accident, but with the intention of making the best of the differences in tax residency determination rules between the then Ireland tax law and the US tax law. Irish tax law

143. Hybrid Mismatch Arrangements: Tax Policy and Compliance Issues, OECD (Mar. 2012), https://www.oecd.org/tax/aggressive/HYBRIDS_ENG_Final_October2012.pdf [https://perma.cc/3Y2K-N2X6].

144. For the actions taken by the OECD in respect to BEPS, see International collaboration to end tax avoidance, OECD, https://www.oecd.org/tax/beps/ [https://perma.cc/EEY2-TSXM] (last visited Aug. 5, 2020).

145. See, e.g., Michael Thom, Tax Politics AND Policy 113 (Routledge 2017); Stephen C. Loomis, The Double Irish Sandwich: Reforming Overseas Tax Havens, 43 ST. MARY's L. J. 825 (2011).

146. Loopholes "provide corporations with abundant opportunities to minimize their tax liability." Wang, supra note 137, at 541. 
provides that a company is a tax resident where its central management and control is located, not where it is incorporated. So, IR Co A is a Bermuda resident (or a tax resident of other tax havens), and not a tax resident in Ireland. However, the [US Internal Revenue Service] treats IR Co A as an Ireland company since it is incorporated in Ireland, which allows it to make full use of all the US treaties with Ireland and Ireland's $12.5 \%$ corporate tax rate, which is one of the lowest corporate tax rate in the world. Additionally, according to US tax law, IR Co A must pay the US Co the arms-length value of intellectual property, and this royalty income is exempted from US corporate taxes under US - Ireland Treaty for US Co, because an Irish company, IR Co A, is in control of the intellectual property.

The next step is to create another Irish subsidiary ("IR Co B"), which is wholly owned by IR Co A and is a tax resident of Ireland. IR Co A then licenses intellectual properties to IR Co B in exchange for royalties. IR Co B then sub-licenses the intellectual properties to some companies outside of the US, and report royalty income to Ireland, but thanks to Ireland's low corporate tax rate and the ability to deduct the royalties paid to IR Co A, IR Co B ends up paying only a "nominal amount in taxes." On the other hand, IR Co A also only pays "a low or nil rate of taxation in Bermuda" for its royalties received from IR Co B.

Ultimate ownership of both IR Co A and IR Co B is located in the United States and therefore they are subject to the [US Internal Revenue Service]'s Controlled Foreign Corporation regulations. The payments between the two related Irish companies might be non-tax-deferrable and subject to current taxation. However, this could be avoided if IR Co B is not a corporation, but a pass-through entity like a partnership, so that it can hide its finances from the [US Internal Revenue Service]. This is possible because a company may choose either to be treated as a corporation or a pass-through entity for tax purposes through the "check the box" rules. If the subsidiary elects to be a passthrough entity, it is treated as a branch of the parent company for tax purposes. Therefore, the payments 
between IR Co A and IR Co B are not subject to current taxation. ${ }^{147}$

A Dutch or Luxembourger twist could be added to the sandwich to shrink the tax burden even further, ${ }^{148}$ in practice resulting in what the OECD has called "double non-taxation." 149 As an illustrative example of the impact of these structures on the tax bills of their beneficiaries, in 2011 Apple (which benefitted from the Double Irish) paid a tax rate of 9.8 percent on its profits, while Wal-Mart (who did not) paid twenty-four percent. ${ }^{150}$ The arrangements leading to drastic tax reductions may have been somewhat suspicious, but they were hard to contest from a legal standpoint. This was particularly so when they came sanctioned by a tax ruling-meaning the tax authorities of the countries enabling these setups were well aware of these practices, and condoned them. As the EC has explained, these rulings sometimes endorse:

. . artificial and complex methods to establish taxable profits for the companies. They do not reflect economic reality. This is done, in particular, by setting [transfer prices] that do not correspond to market conditions. As a result, most of the profits ... are shifted abroad, where they are also not taxed ... ${ }^{151}$

\section{The Harmful Effects of the Tax Schemes of MNEs}

The tax tricks of MNEs have been a source of concern for the international community for decades. Countries that do not have the capital or technology for their economies to flourish may rely on low tax rates to attract foreign investment as a shortcut to economic growth. The low tax carrot thus serves to lure overseas firms to move part of their business to their territories. However, this can lead to harmful tax competition, as it serves to trigger a race to the bottom-where "countries go on

147. Liu, supra note 139, 85-87. See also Wang, supra note 137, at 545-49; Joseph P. Brothers, From the Double Irish to the Bermuda Triangle, TAX NOTES INT'L 687 (Nov. 24, 2014).

148. Liu, supra note 139 , at 87.

149. OECD (2013), supra note 122, at 10, 34, 38, $39 \& 53$.

150. Charles Duhigg \& David Kocieniewski, How Apple Sidesteps Billions in Taxes, N.Y. Times (Apr. 28, 2012) https://www.nytimes.com/2012/04/29/business/applestax-strategy-aims-at-low-tax-states-and-nations.html [https://perma.cc/9Z8X-LXLB].

151. European Commission Press Release IP/15/5880, supra note 121. 
cutting the taxes they impose on foreign investors until the benefit they derive is reduced to zero."152 Moreover, the migration of intangibles carried out to reduce taxes is detrimental for the high tax jurisdictions whose corporations are investing abroad.153 Michael Littlewood identifies two main issues: first, the ensuing decrease in economic activity leads to inter alia job cuts, and second, government revenue takes a plunge, since there is less taxpayers' money. ${ }^{154}$ A study by Eric Bartlesman and Roel Beetsma calculated that, in 2001, the manipulation of profit allocation via transfer pricing by MNEs cost the US $\$ 53$ billion. ${ }^{155}$

Transfer pricing and BEPS may amount to abusive tax avoidance, which has "no business purpose other than tax avoidance." 156 The expertise of the architects behind these operations, their complexity, and the fact that they happen within groups of companies, often complicate the detection of such abuses. ${ }^{157}$ However, they jeopardize the proper functioning of fiscal institutions, and are thus considered detrimental in the developed world and in developing countries alike. ${ }^{158}$

\section{Traditional Means to Tackle Harmful Tax Competition and Tax Avoidance}

The eradication of "harmful tax competition" features prominently in the global agenda. The United States adopted legislation to combat the woes of transfer pricing already in $1928,{ }^{159}$ and many other jurisdictions followed suit, particularly since the 1990s. By 2005, forty countries had regulated these

152. Michael Littlewood, Tax Competition: Harmful to Whom?, 26 MiCH. J. INT'L L. 411,413 (2004).

153. See Roberto Schatan, Cross-Border Migration of Intangibles: Some Tax Policy Considerations, INT'L TAX J. 59, 59 (Nov.-Dec. 2008).

154. Littlewood, supra note 152 , at 413.

155. Eric J. Bartlesman \& Roel M. W. J. Beetsma, Why Pay More?: Corporate Tax Avoidance Through Transfer Pricing in OECD Countries, 87 J. PUB. ECON. 2225 (2003).

156. California Franchise Tax Board, Statement of the California Franchise Tax Board Before the United States Senate Finance Committee (2004), https://www.finance.senate.gov/imo/media/doc/072104dltest.pdf [https://perma.cc/63DA-69PZ].

157. Pearson, supra note 136 , at 542.

158. Hamish Russell and Gillian Brock, Abusive Tax Avoidance and Responsibilities of Tax Professionals, 17 J. HuM. DEV. \& CAPABILITIES 278 (2016).

159. Revenue Act, 45 Stat. 791 (1928). 
practices, ${ }^{160}$ but given their inherently transnational nature, national solutions are not always well suited to address them. They have thus been also addressed in bilateral treaties. Most importantly, the OECD that has become "the main multilateral forum on tax issues through its work on solving double taxation problems caused by the impact of differences across tax systems on entities and individuals operating in more than one jurisdiction." 161 Its work focuses mainly on tackling tax havens and preferential tax regimes. ${ }^{162}$ The prominent role of the OECD is unsurprising, since many of its members are the high tax countries suffering the damaging consequences of profit allocation manipulation in their own skin. However, portraying the issue as a matter of rich countries versus poor countries is an inaccurate oversimplification. ${ }^{163}$ In fact, in the context of the developments covered in this Article, the jurisdictions that enabled the problematic tax schemes also happen to be in the OECD. These issues equally affect the EU, which has taken various strands of action beyond the application of State aid. The EU initiatives to combat corporate tax elusion are the

160. Pearson, supra note 136 , at 574 .

161. Andrew P. Morriss \& Lotta Moberg, Cartelizing Taxes: Understanding the OECD's Campaign Against "Harmful Tax Competition", 4 COLUM. J. TAX L. 1 (2012).

162. See, e.g., OECD, Report on the Attribution of Profits to Permanent ESTABLISHMENTS (July 22, 2010), https://www.oecd.org/ctp/transferpricing/45689524.pdf [https://perma.cc/4RCZ-R5BB7]; OECD, TACKLING AGGRESSIVE TAX Planning THROUgh Improved Disclosure and TRANSPARENCY-REPORT ON Disclosure InITIATIVES (Feb. 2011), http://www.oecd.org/ctp/exchange-of-taxinformation/48322860.pdf [https://perma.cc/TP64-PQAC]; OECD, NEUTRALIZING THE EFFECTS OF BRANCH MISMATCH ARRANGEMENTS (2017), https://www.oecdilibrary.org/docserver/9789264278790-

en.pdf? expires $=1598499736 \&$ id $=$ id $\&$ accname $=$ ocid $40000041 \&$ checksum $=$ A $36047652 \mathrm{CE}$ 1FEC10A8B69F1023E3E4E [https://perma.cc/DCS4-QBQ2]; OECD, TAX CHALLENGES ARISING FROM DIGITALISATION-INTERIM REPORT (2018), https://www.oecdilibrary.org/docserver/9789264293083-

en.pdf?expires $=1598499077 \&$ id $=$ id $\&$ accname $=$ ocid $40000041 \&$ checksum $=7$ EA 804 AEE 1 19B3296CE51636995DC41B [https://perma.cc/8PAW-GS7C]; OECD, supra note 123. Other documents will be referred to where relevant.

163. This is the view portrayed by Morriss \& Moberg, supra note 161, at 3 . They claim that the OECD serves as a means for the United States and Europe "to dominate a virtually impervious institutional architecture of tax policymaking," arguing that "if the OECD is successful in its efforts, jurisdictions will have ceded an important aspect of policy autonomy and sovereignty to an international forum dominated by a small group of industrialized economies with relatively high tax rates. Domestic policy decisions constrained by competition among jurisdictions to attract capital will be transformed into international decisions dominated by a cartel of wealthy nations." Id. 
subject of the next Part of this study. ${ }^{164}$ Here, the focus of the discussion is the work of the OECD.

There are globally accepted mechanisms in place to address profit allocation manipulation tactics, most notably the ALP defined in Article 9 of the OECD Model Tax Convention and further developed in the OECD Transfer Pricing Guidelines. ${ }^{165}$ Essentially, the ALP states that transfer prices should equate those which would have occurred if the operation had instead involved two independent companies, and would thus have been dictated by market forces instead of tax benefits. In fact, the EC also favors the ALP:

... tax administrations should only accept transfer prices between intra-group companies that are remunerated as if they were agreed to by independent companies negotiating under comparable circumstances at arm's length. ${ }^{166}$

The ALP suffers from certain shortcomings. For starters, it emerged in the context of tangible, manufactured goods, in relation to the raw materials needed for their production, but is now being applied to impalpable IP intra-group transfers. ${ }^{167}$ It is also very broad, and needs a specific calculation method. Among the most common methods are transactional methods, which assess "transfer prices . . by transaction basis rather than considering the aggregate financial impact," and valuation methods, based on net worth. ${ }^{168}$ Determining which system is best for each transaction has been the subject of disputes in the EC tax rulings investigations. ${ }^{169}$ These are discussed below. ${ }^{170}$

164. See infra Part IV.

165. OECD, MODEL TAX CONVENTION ON INCOME AND ON CAPITAL, art. 9 (2017), https://www.oecd-ilibrary.org/docserver/g2g972ee-

en.pdf? expires $=1598503477 \& \mathrm{cid}=\mathrm{id} \&$ accname $=$ ocid40000041\&checksum $=937 \mathrm{D} 29 \mathrm{D} 86 \mathrm{E} 0$ 27071B40FFD526EB63600 [https://perma.cc/2FVG-UQG3]; OECD, TRANSFER Pricing GUidelines fOR MUltinational ENTERPRises AND TAX ADMINISTRATIONS (2017), https://www.oecd-ilibrary.org/docserver/tpg-2017en.pdf?expires $=1598503621 \& \mathrm{cid}=\mathrm{id} \&$ accname $=$ ocid $40000041 \&$ checksum $=$ FC1 16 AD23F 1 7A395A0EAF995AA7D080F [https://perma.cc/99XA-Y6SN].

166. Fiat Decision, supra note 140 , para. 85 .

167. Pearson, supra note 136 , at 579.

168. Id. at 579-85.

169. See, e.g., Commission Decision (EU) $2017 / 502$ of 21 October 2015 on State aid implemented by the Netherlands to Starbucks C/2015/7143, 2017 O.J. (L 83/38) [hereinafter Starbucks Decision].

170. See infra Part IV. 
Moreover, for the ALP to function adequately, tax authorities and MNEs must work together in good faith. Unfortunately, this is not always the case, ${ }^{171}$ leading commentators to posit that the "international tax system has failed to prevent multinational enterprises from avoiding paying corporation taxes in jurisdictions where they operate." 172

\section{The Momentum for Action}

Revelations about the obscure tax practices of MNEs ${ }^{173}$ caused public outrage in the 2010s. In April 2012, the New York Times published a piece entitled How Apple Sidesteps Billions in Taxes, exposing the tech company's intricate but profitable Double Irish tax strategy. ${ }^{174}$ Two years later, in November 2014, the International Consortium of Investigative Journalists ("ICIJ") released the Luxembourg Leaks ("LuxLeaks"), a database containing a "confidential cache of secret tax agreements approved by Luxembourg authorities, that provide tax-relief for more than 350 companies around the world." 175 Among the best-known names were Amazon, FedEx, Guardian Media Group, IKEA, Skype, or Vodafone. ${ }^{176}$ Simultaneously, various Group of 8 ("G8") political leaders have outspokenly condemned these arrangements, ${ }^{177}$ widely considered

171. Neighbour, supra note 133.

172. Darcy, supra note 138 , at 4.

173. OECD, TACKLING AgGRessive TAX Planning, supra note 162.

174. Duhigg \& Kocieniewski, supra note 150.

175. Matthew Caruana Galizia et al., Exploring the Documents: Luxembourg Leaks Database, ICIJ (Nov. 5, 2014), https://www.icij.org/investigations/luxembourgleaks/explore-documents-luxembourg-leaks-database/ [https://perma.cc/Q484-8K72]. 176. Id.

177. Angela Merkel stated that "[i]t's not right that giant global companies have huge sales here (in Germany), in all of Europe, in the United States and elsewhere and then only pay taxes somewhere in a tiny tax haven". Tobias Schwarz, Germany's Merkel Calls for G8 Fight Against Tax Havens, REUTERS (Oct. 4, 2012), https://www.reuters.com/article/us-g20-tax-germany-merkel/germanys-merkel-callsfor-g8-fight-against-tax-havens-idUSBRE91C1G020130213 [https://perma.cc/X9AVXEA6]. Similarly, the then UK Prime Minister David Cameron said that the UK wanted to "use the G8 to drive a more serious debate on tax evasion and tax avoidance." David Cameron, U.K. Prime Minister, Speech to the World Economic Forum in Davos (Jan. 24, 2013), https://www.gov.uk/government/speeches/prime-minister-david-cameronsspeech-to-the-world-economic-forum-in-davos [https://perma.cc/55ZF-YAPA]. Former US President Barack Obama, on his part, referred to the importance of "closing tax loopholes for multinational companies" Barack Obama, U.S. President, Remarks at 
"instruments for aggressive tax strategies and undesirable tax avoidance." 178

By the time the LuxLeaks were published, the tax rulings of various EU Member States were already under the EC's radar. But the scrutiny of the tax rulings is only one in an array of strategies to combat these issues. Both the OECD and the EU have taken various strands of action, including the adoption of legislation. The mounting pressure coerced the Irish government to announce changes to its tax laws in order to kill double Irish arrangements for good. ${ }^{179}$ These were implemented by $2015 .{ }^{180}$ Moreover, in January 2020 Google's parent company Alphabet confirmed that it would no longer be relying on the double Irish to distribute its profits among jurisdictions. ${ }^{181}$

\section{THE APPLICATION OF STATE AID LAW TO TAX RULINGS: FIAT, STARBUCKS AND APPLE}

The EU has very limited room to maneuver when it wants to intervene in direct taxation issues. ${ }^{182}$ At the same time, given the potentially harmful implications of corporate tax matters for the general goals of the Union, since the late 1990s it has relentlessly attempted to put the tools at its disposal to good use, and take effective action. Its unyielding interest has led pundits to wonder whether the "narrative" of harmful tax competition may be used a "political instrument for rekindling attention in a

G20 Press Conference (Nov. 16, 2014) https://obamawhitehouse.archives.gov/thepress-office/2014/11/16/remarks-president-obama-g20-press-conference-november-162014 [https://perma.cc/93S7-53QY].

178. Diller et al., supra note 126, at 443. See also OECD, TACKLING AgGressive TAX PLANNING, supra note 162 , at 6.

179. Kelly Phillips Erb, Ireland Declares "Double Irish" Tax Scheme Dead, FORBES (Oct. 15, 2014), https://www.forbes.com/sites/kellyphillipserb/2014/10/15/irelanddeclares-double-irish-tax-scheme-dead/\#2bb399f5fffd [https://perma.cc/WQ5CQB8G].

180. Finance Act, 2014 (Act No. 37/2014) (Ir.).

181. Edward Helmore, Google Says It will No Longer Use the "Double Irish, Dutch Sandwich" Tax Loophole, GUARDIAN (Jan. 1, 2020), https://www.theguardian.com/technology/2020/jan/01/google-says-it-will-no-longeruse-double-irish-dutch-sandwich-tax-loophole [https://perma.cc/7HLD-MZG8].

182. Direct taxation involves people or corporations paying money to tax administrations themselves (e.g., for their income). It is opposed to indirect taxation, paid on purchased goods or services. For general discussions of direct taxation, see MarjaAna Helminen, EU TAX LaW: Direct TAXation (IBDF, 2011). See also MiCHAEL LANG ET AL., INTRODUCTION TO EUROPEAN TAX LAW: DIRECT TAXATION (5th ed. 2018). 
previously neglected policy area." 183 The two main strands of action are legislation (both soft law and binding harmonizing initiatives) and State aid. Both are covered here, with particular emphasis on the latter, after a brief explanation of the origin of the EU's power to interfere with aspects of direct taxation.

\section{A. The EU's Tax Concerns and Competence to Act}

Direct taxation is, in principle, an exclusive competence of the EU Member States. This means that national governments retain full sovereignty over this area, and are free to establish their own tax strategies, subject to international rules and any bilateral treaties they may have entered into. This does not mean, however, that the hands of the EU institutions are completely tied in this field. The regulatory framework allows for some, albeit limited, intervention. Any initiatives have to be targeted at pursuing the general objectives of the EU Treaties, and will naturally only affect the Union's 27 all-European members (rather than the OECD's 37).

It is reasonable for the Union to want to tackle the problems relating to the manipulation of intra-group profit allocation previously described. ${ }^{184}$ Harmful tax competition between the Member States could be a source of undesirable tensions, thus posing a threat to the stability of the integration process. Moreover, tax avoidance can clearly affect the economic prosperity of the Union. The EU's power to act ultimately stems from Article 3(2) of the Treaty on the European Union (TEU), which lists among the principal aims of the EU the "sustainable development of Europe based on balanced economic growth and price stability, a highly competitive social market economy." 185 Until 2009, the Treaty on the European Community (now the TFEU) contained a list of activities that could be carried out in order to achieve those goals. It referred to, inter alia, removing obstacles to free movement, and "ensuring that competition in the internal market is not

183. Claudio M. Radaelli, Harmful Tax Competition in the EU: Policy Narratives and Advocacy Coalitions, 37 J. COMMON MKT. STUD. 661 (1999).

184. See discussion supra Part III.B.2.

185. Consolidated Version of the Treaty on the European Union art. 3(3), July 6 , 2016, 2016 O.J. (C202) 17 [hereinafter TEU] (emphasis added). 
distorted." 186 To this end, the EU institutions would be entrusted with the "approximation of the laws of the Member States required for the functioning of the common [now internal] market."187

Soft law and binding legislation may be adopted "to exercise the Union's competences." 188 Among the former are recommendations and opinions, which state a position on a matter considered important for the Union, and (in the case of recommendations) propose a line of action. As for the latter, the question arises as to how it would be possible to issue a mandatory legal act in the field of direct corporate taxation, when it is not a Union competence. A fundamental provision in this regard is Article 115 TFEU. It allows the Council to "issue directives ${ }^{189}$ for the approximation of such laws, regulations or administrative provisions of the Member States as directly affect the establishment or functioning of the internal market." 190 This means that the Council can compel the members of the EU to make changes to their national laws if these bear a direct impact on the much-coveted fruit of the integration process. Consequently, if fiscal provisions affect this purpose, the EU can arguably step in and adopt legislation forcing its members to introduce legislative amendments to fix the issue(s) at stake and guarantee the protection of the internal market. Unanimity is required to adopt directives relying on Article 115 TFEU. ${ }^{191}$ It has served as legal basis for the tax laws that have been adopted to date, including the Anti-Tax Avoidance Directive. ${ }^{192}$

The fundamental principles of EU law also play a key role here, in particular the principles of supremacy and of subsidiarity. According to the former, " $[\mathrm{w}]$ here Union law exists, it is supreme in relation to national law, and will prevail in the

186. Treaty on the European Community art. 3, 2002, 2002 O.J. (C 325).

187. Id.

188. TFEU, supra note 19, art. 288.

189. A directive is a legal act of the EU which is "binding, as to the result to be achieved, upon each Member State to which it is addressed, but [leaves] to the national authorities the choice of form and methods." TFEU, supra note 19, art. 288.

190. TFEU, supra note 19 , art. 115 .

191. Id.

192. See generally Council Directive (EU) 2016/1164 of 12 July 2016 laying down rules against tax avoidance practices that directly affect the functioning of the internal market, 2016 O.J. (L 193/1). 
event of ... any conflict." 193 The latter implies that "in areas which do not fall within its exclusive competence, the Union shall act only if and in so far as the objectives of the proposed action cannot be sufficiently achieved by the Member States, either at central level or at regional and local level, but can rather, by reason of the scale or effects of the proposed action, be better achieved at Union level."194

On the basis of these objectives, tools and principles, it is possible to identify three lines of action at the EU level regarding direct taxation. These are: soft law, harmonizing legislation, and State aid rules. The first two are briefly discussed below. The third forms the core of the analysis conducted in this Part of the Article.

\section{B. Regulating Direct Taxation at the EU Level}

The lack of homogenous rules on corporate direct taxation across Europe can hamper the internal market. The disparities can act as an obstacle to free movement of goods, people (including workers) and capital. ${ }^{195}$ The attempts to iron out the differences via binding legislation and soft law seek neutrality, that is, "to minimize the effect of taxes on private economic decisions." 196

\section{Non-Binding Measures}

Already in the late 1990s, the Council published an EU Code of Conduct for Business Taxation. ${ }^{197}$ While not legally binding, it acknowledges the importance of coordinated action to combat harmful tax competition, tax avoidance and tax

193. MARCO COLINO, supra note 40, at 50. See also TEU, supra note 185 , art. 4(3); see generally Case 6/64, Flaminio Costa v. E.N.E.L., 1964 E.C.R. 585, C.M.L.R. 425 (1964).

194. TEU, supra note 185 , art. 5(3). See also Case 56/65, La Technique Minière v. Maschinenbau Ulm GmbH 1 C.M.L.R. 357 (1966).

195. Oleksandr Pastukhov, Counteracting Harmful Tax Competition in the European Union, 16 SW. J. INT'L L. 159, 160 (2010).

196. Id.

197. ECOFIN COUNCIL, CONCLUSiOnS OF THE ECOFIN COUNCIL MEETING ON 1 DeCEMber 1997 Concerning TaXation Policy, annex 1, 1997 O.J. (C 2/2). See also Jacques Malherbe \& Robert Boon, Harmful Tax Competition and the European Code of Conduct, 28 INT'L BUS. L. 339 (2000). 
evasion, ${ }^{198}$ and stresses the need to prevent losses from tax revenue-all of this with a view to protecting the internal market. Its main concern centers around those systems that offer special tax advantages for non-residents, so as to lure them into doing business in their territory. In addition to setting out some criteria to determine when tax competition might be harmful, ${ }^{199}$ the Code of Conduct includes a commitment of "standstill" and a commitment of "rollback": the Member States will not introduce new measures amounting to harmful tax competition, 200 and will amend any existing ones that might be detrimental. ${ }^{201}$ Interestingly, the Code refers to the possibility of applying State aid to damaging measures, and pledges to publish guidelines on the application of these rules to direct business taxation. ${ }^{202}$ Its adoption led to the creation of a Code of Conduct Group (Business Taxation) in March 1998, and the publication of a list of harmful tax measures just over a year later. ${ }^{203}$

In January 2016, the EG launched an Anti-Tax Avoidance Package, undoubtedly the most important step to date in this area. ${ }^{204}$ The impetus of this development came from the OECD's Action Plan on BEPs, propelled by the leaders of the Group of 20 ("G20") in 2013.205 In the Action Plan, the OECD aimed to "provide countries with domestic and international instruments that will better align rights to tax with economic activity,"206 and suggested specific actions, with references to deadlines, resources and methodologies for implementation. ${ }^{207}$ Importantly, in addition to various communications and

198. CODE OF CONDUCT, supra note 179 , para. K.

199. Id. para. B.

200. Id. para. C.

201. Id. para. D.

202. Id. para. J. 1999),

203. See Code of Conduct Group, Report to ECOFIN Council, SN 4901/99 (Nov. 23,

https://ec.europa.eu/taxation_customs/sites/taxation/files/resources/documents/pr imarolo_en.pdf [https://perma.cc/93RR-SL6U].

204. Anti Tax Avoidance Package, Eur. COMM'N, https://ec.europa.eu/taxation_customs/business/company-tax/anti-tax-avoidancepackage_en [https://perma.cc/9FMJ-DZEU] (last visited Aug. 5, 2020).

205. OECD, ACTION PLAN ON BEPS (2013).

206. Id. at 11 .

207. Id. at 13-26. 
recommendations and a study of aggressive tax planning, ${ }^{208}$ the Package also put forward legislative proposals. In particular, it anticipated changes to the Directive on Administrative Cooperation and, fundamentally, it tabled the draft of what would become the Anti-Tax Avoidance Directive. ${ }^{209}$ The binding legislation is discussed below, in the subpart relating to harmonization.

On July 15, 2020, the day the Apple judgment was handed down by the GC, the Commission adopted a new Tax Package, ${ }^{210}$ with three documents: (1) an Action Plan, ${ }^{211}$ with initiatives to inter alia help Member States enforce tax rules and ensure compliance, so as to guarantee tax revenue; (2) a proposed revision to the Directive on Administrative Cooperation, ${ }^{212}$ mainly extending tax transparency rules to digital platforms; $; 13$ and (3) a Communication on Tax Good Governance to consider how the EU can enhance transparency and fair taxation (including by revising the Code of Conduct). ${ }^{214}$ In all of these initiatives there are frequent references to the work of the OEGD. ${ }^{215}$

208. See Package for Fair and Simple Taxation, EuR. Comm'N, https:/ / ec.europa.eu/taxation_customs/general-information-taxation/eu-tax-policystrategy/package-fair-and-simple-taxation_en [https://perma.cc/C5AQ-S9MA] (last visited Aug. 5, 2020).

209. Anti Tax Avoidance Package, supra note 204.

210. Id.

211. Communication from the Commission to the European Parliament and the Council, An Action Plan for Fair and Simple Taxation Supporting the Recovery Strategy, EuR. COMm'N (July 15 , 2020), https://ec.europa.eu/taxation_customs/sites/taxation/files/2020_tax_package_tax_ac tion_plan_en.pdf [https://perma.cc/HH2Q-8XL8].

212. Council Directive 2011/16/EU of 15 February 2011 on administrative cooperation in the field of taxation and repealing Directive 77/799/EE, 2011 O.J. (L 64/1) [hereinafter Directive on Administrative Cooperation].

213. Proposal for a Council Directive amending Directive 2011/16/EU on Administrative Cooperation in the Field of Taxation, EuR. COMMISSION (July 15, 2020), https://ec.europa.eu/taxation_customs/sites/taxation/files/2020_tax_package_dac7_ en.pdf [https://perma.cc/XCH2-XH8G].

214. Communication from the Commission to the European Parliament and the Council, Tax Good Governance in the EU and Beyond, EuR. CoMM'N (July 15, 2020), https://ec.europa.eu/taxation_customs/sites/taxation/files/2020_tax_package_tax_g ood_governance_communication_en.pdf [https://perma.cc/589V-EUXR].

215. See, e.g., id. at 4 n.7. 


\section{Harmonizing Legislation}

The first direct taxation-related area in which EU secondary legislation was adopted, dating as far back as in 1977, was that of cooperation between the tax authorities of the Member States.216 The logic for this move was that increasing transparency would help minimize the risks of tax avoidance. Moreover, regulating inter-agency cooperation is politically more acceptable than tampering with substantive aspects of indirect taxation regulation. It should be remembered that this is an area in which the Member States are hesitant about EU interference, and thus the EU institutions need to tread lightly. In 2011, the Directive on Administrative Cooperation was passed, ${ }^{217}$ with a view to ensuring "that all taxpayers pay their fair share of the tax burden, irrespective of where they work retire, hold a bank account and invest or do business." 218 The Directive covers information exchanges between the Member States relating to tax matters, effectively setting up an automatic information exchange system to collect data on income earned by nonresidents. ${ }^{219}$ That information is then transmitted to the countries where the taxpayers reside. ${ }^{220}$ In 2014, the scope of the Directive was expanded so that interest, dividends, account balances and sales proceeds from financial assets would also be included.221 In 2018, new mandatory disclosure rules were introduced, ${ }^{222}$ effectively incorporating the OECD's Mandatory Disclosure Rules into EU law.223

216. Council Directive 77/799/EEG of 19 December 1977 concerning mutual assistance by the competent authorities of the Member States in the field of direct taxation, 1977 O.J. (L 336/15).

217. Directive on Administrative Cooperation, supra note 212.

218. Administrative Cooperation in (Direct) Taxation in the EU, EUR. COMM'N, https://ec.europa.eu/taxation_customs/business/tax-cooperationcontrol/administrative-cooperation/enhanced-administrative-cooperation-field-directtaxation_en [https://perma.cc/LGE8-8DLH] (last visited Aug. 5, 2020).

219. Directive on Administrative Cooperation, supra note 212, ch. II.

220. Id.

221. See Council Directive 2014/107/EU of 9 December 2014 amending Directive $2011 / 16 / \mathrm{EU}$ as regards mandatory automatic exchange of information in the field of taxation, 2014 O.J. (L 359/1).

222. See Council Directive (EU) 2018/822 of 25 May 2018 amending Directive $2011 / 16 / \mathrm{EU}$ as regards mandatory automatic exchange of information in the field of taxation in relation to reportable cross-border arrangements, 2018 O.J. (L 139/1).

223. OECD, MOdel MANDATORY Disclosure Rules FOR [COMMON REPORTING STANDARD] ARRANGEMENTS AND OPAQUE OFFSHORE STRUCtURES (Mar. 9, 2020), 
The most important step towards the harmonization of direct taxation laws to date is the Anti-Tax Avoidance Directive, adopted in 2016 as part of the Anti-Tax Avoidance Package. ${ }^{224}$ It was passed by unanimity in the Council, relying on the powers conferred on the EU institutions by Article 115 TFEU. Given the sensitivity of the area, a detailed justification for the Directive's enactment is provided, invoking the impossibility to tackle the problem at the national level and insisting on the full respect to the principle of subsidiarity: 225

Considering that a key objective of this Directive is to improve the resilience of the internal market as a whole against cross-border tax avoidance practices, this cannot be sufficiently achieved by the Member States acting individually. National corporate tax systems are disparate and independent action by Member States would only replicate the existing fragmentation of the internal market in direct taxation. It would thus allow inefficiencies and distortions to persist in the interaction of distinct national measures. The result would be lack of coordination. Rather, by reason of the fact that much inefficiency in the internal market primarily gives rise to problems of a cross-border nature, remedial measures should be adopted at Union level. It is therefore critical to adopt solutions that function for the internal market as a whole and this can be better achieved at Union level. Thus, the Union may adopt measures, in accordance with the principle of subsidiarity as set out in Article 5 of the Treaty on European Union. In accordance with the principle of proportionality, as set out in that Article, this Directive does not go beyond what is necessary in order to achieve that objective. By setting a minimum level of protection for the internal market, this Directive only aims to achieve the essential minimum degree of coordination within the Union for the purpose of materialising its objectives. ${ }^{226}$

https://www.oecd.org/tax/exchange-of-tax-information/model-mandatory-disclosurerules-for-crs-avoidance-arrangements-and-opaque-offshore-structures.pdf [https://perma.cc/9SFN-56F3].

224. See supra Part IV.B.1.

225. See supra Part IV.A.

226. Anti Tax Avoidance Package, supra note 204, para. 16. 
The Directive compels the Member States to introduce five measures in their tax regimes: limits on interest deductions, ${ }^{227}$ exit taxation, ${ }^{228}$ general anti-abuse rule, ${ }^{229}$ controlled foreign company rule, ${ }^{230}$ and tackling hybrid mismatches. ${ }^{231}$ The EU countries had until January 1, 2019 to transpose the Directive into their national laws by making any required legislative amendments, but in January 2020 six of them were issued with a formal notice for not having complied with the deadline. ${ }^{232}$ The Anti-Tax Avoidance Directive was amended in 2017 to cover hybrid mismatches arrangements with third countries. ${ }^{233}$ That same year, the Tax Dispute Resolution Directive was adopted to facilitate settling tax related disputes.234 The Member States must resort to compulsory and binding arbitration, committing to solving the issue within a specified time frame and with the possibility of going to court as a last resort.

\section{The EC's Application of State Aid Law to Tax Rulings}

The pivotal regulatory steps described above are forwardlooking: they aim at avoiding future problems by compelling the Member States to take action. As such, they are undoubtedly the most powerful weapon against tax competition and tax avoidance. However, they do not have retroactive effect, and cannot be used to hand out substantial bills for unpaid taxes to those that, in the past, may have manipulated their profit allocation, or relied on hybrid mismatches to avoid taxes. By contrast, State aid law provides an opportunity to dig into the past: if the APA endorsing a corporation's tax scheme is contrary to Article 107(1) TFEU, then any associated benefits would

227. Id. art. 4.

228. $I d$. art. 5 .

229. $I d$. art. 6.

230. $I d$. art. 7-8.

231. Id. art. 9.

232. For an analysis of the Directive, see Peter Koerver Schmidt, The Role of the Anti-Tax Avoidance Directive in Restoring Fairness-A Proper Step towards Ensuring Sustainability of the International Tax Framework?, in TAX SUSTAINABILITY IN AN EU AND INTERNATIONAL CONTEXT (C. Brokelind \& Servaas van Thiel eds., 2020).

233. Council Directive (EU) 2017/952 of 29 May 2017 Amending Directive (EU) 2016/1164 as Regards Hybrid Mismatches with Third Countries, 2017 O.J. (L 144) 1. It is mentioned by the OECD on its website, since it affects its members.

234. Council Directive (EU) 2017/1852 of 10 October 2017 on tax dispute resolution mechanisms in the European Union, 2017 O.J. (L 265/1). 
constitute illegal State aid, allowing the EC to oblige the relevant company to give back the advantage received by paying the taxes it would normally have owed. But the principal reason for resorting to these provisions resides not in their retroactive potential. Contrary to the field of direct taxation, State aid law is an exclusive competence of the EU. ${ }^{235}$ As a consequence, it furnishes the Commission with much broader enforcement powers, and their exercise does not require the consent of the member States.

The EC first started investigating the "sweetheart deals" offered by national tax authorities to MNEs in 2013, a year before the LuxLeaks scandal hit the spotlight, ${ }^{236}$ and coinciding with the OECD's Action Plan on BEPS. ${ }^{237}$ By the end of 2014, a general information inquiry into tax rulings had extended to all Member States.238 As of August 2020, twelve specific investigations had been launched, ${ }^{239}$ of which eight had already concluded. ${ }^{240}$ In seven of these cases, the EC found that there

235. TFEU, supra note 19, art. 3(1) (b).

236. See supra Part III.C.

237. See OECD, ACTION PLAN ON BEPS, supra note 205.

238. European Commission Press Release IP/14/1742, State Aid: Commission Extends Information Enquiry on Tax Rulings Practice to All Member States (Dec. 17, 2014), https://ec.europa.eu/commission/presscorner/detail/es/IP_14_2742 [https://perma.cc/WJ6W-78FY].

239. As of August 2020, the EC is currently investigating the following: the tax treatment of Inter IKEA in The Netherlands, European Commission Press Release IP/17/5343, State Aid: Commission Opens In-depth Investigation into the Netherlands' Tax Treatment of Inter IKEA (Dec. 18, 2017), https://ec.europa.eu/commission/presscorner/detail/en/IP_17_5343

[https://perma.cc/D58Y-PGUG]; the tax treatment of Nike in The Netherlands, European Commission Press Release IP/19/322, State Aid: Commission Opens Indepth Investigation into Tax Treatment of Nike in the Netherlands (Jan. 10, 2019), https://ec.europa.eu/commission/presscorner/detail/en/IP_19_322

[https://perma.cc/8FXN-B8Q8]; the tax treatment of Huhtamäki in Luxembourg, European Commission Press Release IP/19/1591, State Aid: Commission Opens Indepth Investigation into Tax Treatment of Huhtamäki in Luxembourg (Mar. 7, 2019), https://ec.europa.eu/commission/presscorner/detail/en/IP_19_1591

[https://perma.cc/C623-U8V8]; the Belgian excess profit exemption for 39 MNEs, European Commission Press Release IP/19/5578, State Aid: Commission Opens Indepth Investigations into Individual "Excess Profit" Tax Rulings Granted by Belgium to 39 Multinational Companies (Sept. $\quad 16, \quad 2019$ ), https://ec.europa.eu/commission/presscorner/detail/en/IP_19_5578 [https://perma.cc/ENS8-99XF].

240. As of September 2020, in addition to the decisions relating to Fiat, Starbucks and Apple, the following have been adopted: Commission Decision (EU) 2016/1699 of 11 January 2016 on the excess profit exemption State aid scheme implemented by 
was unlawful State aid. ${ }^{241}$ According to Vestager, the tax systems sanctioned may "artificially reduce a company's tax burden," and are therefore "not in line with EU state aid rules. They are illegal." ${ }^{42}$ On appeal, thus far only once, in Fiat, has a finding of illegal State aid been upheld by the GC. ${ }^{243}$ The positions of the EC and the GC provide an accurate predictor of the viability of State aid as a tool to combat detrimental tax competition and tax evasion. It should be noted however that the CJ has not yet issued any rulings on the application of State aid to APAs. Appeals against the judgments of the GC in Fiat and Apple were pending at the time of writing. ${ }^{244}$

\section{The Tax Systems Endorsed}

The investigation into Fiat's tax scheme related to an APA granted by Luxembourg in 2012 to the company Fiat Finance and Trade ("FFT"), sited in its territory. FFT offers financing and treasury services to other Fiat companies located in different parts of Europe. ${ }^{245}$ According to the EC, the tax ruling "endorses a method for arriving at a profit allocation to FFT within the Fiat group ... and enables FFT to determine its corporate income tax liability to Luxembourg on a yearly basis." 246 The transactional net margin method (TNMM) was used to

Belgium, 2016 O.J. (L 260/61); Commission Decision (EU) 2018/859 of 4 October 2017 on State aid implemented by Luxembourg to Amazon, 2018 O.J. (L 153/1); Commission Decision (EU) 2019/421 of 20 June 2018 on State aid implemented by Luxembourg in favor of ENGIE, 2019 O.J. (L 78/1); Commission Decision (EU) 2019/1252 of 19 September 2018 on tax rulings granted by Luxembourg in favor of McDonald's Europe, 2019 O.J. (L 195/20); Commission Decision (EU) 2019/1352 of 2 April 2019 on the State aid SA.44896 implemented by the United Kingdom concerning CFC Group Financing Exemption, 2019 O.J. (L 216/1). The updated developments can be found at Tax Rulings, Eur. COMM'N, https://ec.europa.eu/competition/state_aid/tax_rulings/index_en.html [https://perma.cc/NFE9-5QRL] (last visited Nov. 13, 2020).

241. See, e.g., Commission Decision (EU) 2019/1252 of 19 September 2018 on tax rulings granted by Luxembourg in favor of McDonald's Europe, 2019 O.J. (L 195/20) (concluding that no illegal state aid had been granted).

242. European Commission Press Release IP/15/5880, supra note 121.

243. Fiat Judgment, supra note 8.

244. See Case C-885/19, Fiat Chrysler Finance Europe v. Commission (filed Dec. 4, 2019); Statement by Vestager, supra note 9.

245. Fiat Decision, supra note 140, para. 36.

246. Id. para. 52. 
calculate the taxable profits, ${ }^{247}$ since according to the tax advisor it was the most appropriate manner of applying the ALP. ${ }^{248}$ This was because FFT only performed financial services, and only to Fiat group companies that "do not receive any similar type of services by third parties," 249 therefore making an internal comparison impossible. What would need to be determined is the "net margins that would have been earned in comparable transactions by independent enterprises." 250 With a view to applying the TNMM, FFT segregated its capital according to the different activities it engaged in, and its taxable profits did not include "the portion of FFT's equity it designated as supporting FFT's financial investments in [Fiat Finance North America ("FFNA")] and [Fiat Finance Canada ("FFC")]."251

In the case relating to Starbucks, ${ }^{252}$ the tax 2008 ruling of the Dutch tax administration was issued in favor of the company Starbucks Manufacturing EMEA BV ("SMBV"), controlled by the Starbucks Corporation-the "only wholly controlled Starbucks group entity outside of the US which roasts coffee." 253 The purpose of the APA, which had a duration of 10 years, was to establish the remuneration of SMBV for the functions it performed. It would consist of a "mark-up of [9-12\%] of the relevant cost base," 254 mainly production and distribution related costs, such as personnel and equipment. The cost of consumables (such as cups, napkins or beans), and of services provided by third parties, were excluded. The APA also accepted the royalty payments for the use of Starbucks' coffee roasting IP

247. The TNMM "examines a net profit indicator, i.e. a ratio of net profit relative to an appropriate base (e.g. costs, sales, assets), that a taxpayer realises from a controlled transaction (or from transactions that are appropriate to aggregate) with the net profit earned in comparable uncontrolled transactions." OECD, TRANSFER PRICING METHODS para. 14 (2010), https://www.oecd.org/ctp/transfer-pricing/45765701.pdf [https://perma.cc/K666-9R64] (last visited Aug. 5, 2020). The ALP is determined "by reference to the net profit indicator that the same taxpayer earns in comparable uncontrolled transactions (internal comparables), or by reference to the net profit indicator earned in comparable transactions by an independent enterprise (external comparables)." Id.

248. Fiat Decision, supra note 140, para. 55.

249. Id.

250. Id.

251. Id. para. 69.

252. Starbucks Decision, supra note 169.

253. Id. paras. $1,39-40$.

254. Id. para. 43. 
and know-how would be "deductible for corporate income tax purposes and ... not subject to Dutch withholding tax." 255 On the basis of this remuneration, SMBV's taxable profits were calculated relying on Dutch corporate income tax, and applying the TNMM.

With regard to Apple, the Irish revenue issued a tax ruling in 1991, and a revised version in 2007. ${ }^{256}$ Both related to the tax systems of Apple Sales International ("ASI") and Apple Operations Europe ("AOE"). The former bought Apple products from all over the world and sold them in Europe, Middle East, Africa and India. Since customers were contractually purchasing the goods from ASI, all the related profits were recorded in Ireland.257 The latter manufactured computers, such as iMac desktops and MacBook laptops, for the Apple group. ${ }^{258}$ According to the Irish law in force at the time, ASI and AOE could be incorporated in Ireland without being tax residents there, since they were managed and controlled by Apple Inc., a tax resident in the US. ${ }^{259}$ Their profits were internally assigned (through transfer pricing relating to IP rights licensed to ASI and AOE) to their head offices, but these lacked "any physical presence or employees and [were] not located in any jurisdiction," 260 and did not have the capacity to generate income from trading. This income thus amounted to "ocean profits," not subject to taxation either in the US or Europe. ${ }^{261}$ In 2011, of ASI's US $\$ 22$ billion in proceeds, only around EU€50 million were taxable in Ireland. ${ }^{262}$ That is how its effective tax rate was calculated by the EC to amount to about 0.05 percent, dropping even further in subsequent years. ${ }^{263}$

255. Id. para. 45 .

256. Apple Decision, supra note 2.

257. Apple Decision, supra note 2.

258. Id. paras. 56-57.

259. Id. paras. $45,49-50$.

260. Id. para. 51 .

261. See Adolfo Martín Jiménez \& Jorge Piernas López, The Apple Case: Who Wins? What's Next?, EU L. LIVE (July 17, 2020), https://eulawlive.com/op-ed-the-apple-casewho-wins-whats-next-by-adolfo-martin-jimenez-and-jorge-piernas-lopez/

[https://perma.cc/T5XL-FSG9].

262. Apple Decision, supra note 2.

263. Id. paras. 355-339. 
2. Application of Article 107-State Imputability, State Resources, Affection of Intra-EU Trade and Distortion of Competition

The Commission had no problem finding that the contested rulings were imputable to the State, since the issuing authorities are part of the tax administration of the relevant EU countries. ${ }^{264}$ It also easily concluded that the APAs involved State resources. While there was no positive transfer of funds, tax exemptions give "rise to a loss of State resources," which also falls within the scope of Article 107,265 as previously discussed. ${ }^{266}$ The requirement that intra-Union trade be affected was equally met in all three cases: the relevant companies are globally active and operating in all EU Member States and therefore "any aid in [their] favour is liable to affect intra-Union trade." 267 Competition could be distorted because the APAs relieve these companies of tax liability they "would otherwise have been obliged to pay" under the ordinary taxation rules, thereby improving their financial position vis-à-vis competitors..$^{268}$

\section{Application of 107-Selective Advantage}

Unsurprisingly, the tricky issue in all of these cases was whether there was a selective advantage. In order to apply State aid law to these tax rulings, the EC had to resort to innovative arguments. It is here where the GC found, on two out of three occasions, that the EC had not done enough to demonstrate an advantage had in fact been conferred.

The analysis of the existence of an advantage and its selective character appears intertwined in all of the decisions.

264. Fiat Decision, supra note 140, para. 18; Starbucks Decision, supra note 169, para. 225; Apple Decision, supra note 2, para. 221.

265. Fiat Decision, supra note 140, para. 188; Starbucks Decision, supra note 169, para. 226 (citing Joined Cases C-106/09 P and C-107/09 P Comm'n v. Government of Gibraltar \& United Kingdom ECLI:EU:C:2011:732, para. 72 (confirming that a tax exemption which "places the persons to whom it applies in a more favourable financial situation than other taxpayers" constitutes State aid)). See also Apple Decision, supra note 2, para. 221.

266. See supra Part II.C.2.a.

267. Fiat Decision, supra note 140, para. 189; Starbucks Decision, supra note 169 , para. 226; Apple Decision, supra note 2, para. 222.

268. Fiat Decision, supra note 140, para. 189; Starbucks Decision, supra note 169 , para. 226; Apple Decision, supra note 2, para. 222. 
The three-step test to assess selectivity discussed above (identifying a framework of reference, demonstrating the existence of a derogation from that framework, and considering possible justifications) is used. ${ }^{269}$ According to the EC, when assessing tax measures, a derogation from the reference system should be sufficient to identify an advantage for the beneficiary. ${ }^{270}$ Given the specificities of the decisions, each case is discussed separately.

\section{a. Luxembourg's Tax Ruling in Favor of Fiat}

The EC used as the reference system "general Luxembourg corporate tax system in the form of the Luxembourg corporate income tax rules" for all corporations, without making a distinction between integrated and non-integrated companies (i.e. those which are part of a group, and those which are not). ${ }^{271}$ The APA amounted to a derogation from the system because it did not respect the ALP, since it lowered the company's tax liability in Luxembourg "compared to nonintegrated companies whose tax base is determined by the profits they generate under market conditions." 272 An advantage existed because this was a specific measure (as opposed to a general scheme), and it could be considered presumptively selective. ${ }^{273}$ The argument of the EC in this regard was that because the APA was not a scheme, and therefore not part of the usual framework, it furnished FFT with an advantage because it was in a better position than it would have been under normal market conditions. ${ }^{274}$

The Commission found that, while in this specific case the TNMM would be the correct method to apply the ALP, it had not been adequately relied upon. The problem rested on the choice of profit level indicator. In particular, all of FFT's capital should have been taken into account, and subjected to a single

269. See supra Part II.C.2.d.

270. Starbucks Decision, supra note 169, para. 253; Apple Decision, supra note 2, para. 225 .

271. Fiat Decision, supra note 140, paras. 209, 215.

272. Id. para. 231.

273. Id. para. 218.

274. Commission Decision (EU) 2016/2326 of 21 October 2015 on State aid which Luxembourg granted to Fiat, 2016 O.J. (L 351), paras. 216, 218. 
rate. ${ }^{275}$ In the related press release, the EC explained that FFT operates like a bank, so its taxable profits should be determined similarly (by calculating the "return on capital deployed ... for its financing activities"). ${ }^{276}$ As a consequence of the flawed application of the TNMM, the capital base calculated was lower than FFT's actual capital, and the remuneration applied to the same was much lower than market rate. ${ }^{277}$ No adequate justification was put forward by Luxembourg nor FFT, 278 and thus in the eyes of the $\mathrm{EC}$ all the requirements for a selective advantage were met. ${ }^{279}$

\section{b. The Dutch APA for Starbucks}

The reference system was the general Dutch corporate income tax system. ${ }^{280}$ Determining a potential derogation would entail assessing "whether the methodology accepted by the Dutch tax administration ... for the determination of SMBV's taxable profits in the Netherlands departs from a methodology that results in a reliable approximation of a market-based outcome and thus from the arm's-length principle." ${ }^{281}$ Unlike in the Fiat case, here the Commission found that the correct technique for calculating taxable profit should have been the comparable uncontrolled price ("CUP") method. ${ }^{282}$ The CUP "compares the price charged for property or services transferred in a controlled transaction to the price charged for property or services transferred in a comparable uncontrolled transaction in comparable circumstances." 283 The preference for this method is consistent with the OECD's position, according to which:

Where it is possible to locate comparable uncontrolled transactions to apply it, the CUP method is the most direct and reliable way to apply the arm's length principle.

275. Id. \$ 7.2.2.3.

276. European Commission Press Release IP/15/5880, supra note 121.

277. Fiat Decision, supra note $140, \S 7.2 .2 .6$.

278. Id. para. 337.

279. Id. para. 339.

280. Starbucks Decision, supra note 169, para. 232.

281. Id. para. 263.

282. Id. $\$ 2.3 .1$.

283. OECD, TRANSFER PRICING METHODS, supra note 247, para. 4. 
Consequently, in such cases the CUP method is preferable over all other methods. ${ }^{284}$

The use of the TNMM, according to the EC, was based on the (wrong) assumption that SMBV was a low-risk manufacturer whose main activity was roasting coffee. 285 It led to unduly reducing the company's taxable profit. Moreover, the TNMM was also "improperly applied," because it did not consider whether the royalty payment for the licensing of the coffee roasting IP respected the ALP ${ }^{286}$ As a consequence, the ALP was not met, and the methodology chosen led "to a lowering of SMBV's tax liability under the general Dutch corporate income tax system as compared to non-integrated companies whose taxable profits is [sic] determined by the market." None of the justifications suggested by the Netherlands and Starbucks were sufficiently substantiated, according to the EC. 287 Therefore, a selective advantage was found to exist.

\section{c. Apple's Tax Ruling in Ireland}

The reference system here was the general Irish corporate tax system. ${ }^{288}$ As in Fiat and Starbucks, the EC pointed out that, in the process of demonstrating the second step of the selectivity test (the derogation), an advantage would be demonstrated, since "where a tax measure results in an unjustified reduction of the tax liability of a beneficiary that would otherwise be subject to a higher level of tax under the ordinary rules of taxation, that reduction constitutes both the advantage granted by the tax measure and the derogation from the reference system."289 It found that the taxable profit calculated on the basis of the profit allocation methods endorsed by the contested APAs departed "from a reliable approximation of a market-based outcome in line with the [ALP]," and thus constituted a selective advantage. ${ }^{290}$ This was partly because the profit level indicator was that of operating costs (rather than sales for ASI and total

284. Id. para. 25.

285. Starbucks Decision, supra note 169, para. 92.

286. Id. para. 378.

287. Id. paras. 317-318, 341 \& 359-361.

288. Apple Decision, supra note 2, para. 227.

289. Id. para. 224.

290. Id. para. 258. 
costs for AOE). As a consequence, the annual taxable profit of the companies was inadequately lowered, particularly when compared to that of non-integrated companies,291 thereby reducing the two companies' corporate tax liability. ${ }^{292}$ Since the EC did not find that the derogation could be justified, the tax ruling was considered to constitute illegal State aid. ${ }^{293}$ The EU€13 billion bill Apple was required to pick up is the biggest of any such investigation to date.

\section{The General Court's Position}

The appeals of these three decisions before the GC had clear commonalities. For starters, they all questioned the use of State aid rules to condemn individual tax rulings, which in the appellants' view amounted to a breach of the exclusive competence of the Member States in the field of direct taxation. They also saw in the acceptance of the ALP an attempt to implement an alien principle into national law.294 The outcome was mostly in line with established case law. The GC agreed with the EC's analysis of the three straightforward conditions of Article 107(1) TFEU, namely State imputability, effect on trade between the Member States, and distortion of competition.295 The bone of contention, and the reason why ultimately the EC lost two of the cases, was the existence of a selective advantage. ${ }^{296}$

The focus of this Section of the Article is assessing the GC's view in relation to (1) whether the disputed decisions amounted to disguised tax harmonization and (2) how a selective advantage can be demonstrated in cases relating to tax measures.

\section{Disguised Harmonization?}

One of the principal issues at stake was whether the EC was entitled to apply State aid law to tax rulings in the first place. According to the appellants, this was a harmonization attempt in

291. Id. para. 345 .

292. Id. para. 223.

293. Apple Decision, supra note 2, art. 1.

294. See GORMSEN, supra note 17 , at 2.

295. TFEU, supra note 19 , art. 107(1).

296. Id. See also, e.g., Case C-15/14, Comm'n v. MOL Magyar Olaj-és Gázipari Nyrt, ECLI:EU:C:2015:32 (Jan. 22, 2015). 
disguise, ${ }^{297}$ which would constitute a "breach of the fundamental constitutional principles of the EU legal order governing the division of competences between the Union and the Member States." ${ }^{998}$ In particular, they invoked the fundamental principles of EU law enshrined in Articles 4 and 5 TFEU,299 as well as Article 114 (which excludes the possibility of adopting harmonizing measures relating to fiscal provisions without unanimity). 300

In this regard, the Commission had cited established case law in that "a Member State may not invoke provisions prevailing in its domestic legal system to justify failure to observe obligations arising under Union law." 301 The GC recognized that direct taxation indeed falls within the realm of exclusive competence of the Member States. However, the Member States are under an obligation to exercise their competence in a manner that is consistent with EU law, including State aid rules, as long as the conditions for their application are met. ${ }^{302}$ While in principle it is up to each country to decide inter alia the bases of assessment and other conditions, if the EC is not afforded any leeway in this regard, it would be impossible to apply Article 107 TFEU. As a consequence:

. . . if such a measure in fact discriminates between companies that are in a comparable situation with regard to the objective of that tax measure and as a result confers selective advantages on the beneficiaries of the measure which favour "certain" undertakings or the production of "certain" goods, it can be considered State aid within the meaning of Article 107(1) TFEU. ${ }^{303}$

The GC was unequivocal that "the Commission merely exercised its powers under Article 107 TFEU in examining whether the tax ruling at issue complied with the law on State

297. Fiat Judgment, supra note 8, para. 100; Starbucks Judgment, supra note 8, para. 158.

298. Apple Judgment, supra note 1, para. 103.

299. See supra Part IV.A.

300. See, e.g., Lux. v. Comm'n, ECLI:EU:T:2019:670.

301. Case C-317/14, Comm'n v. Belg., ECLI:EU:C:2015:63 (Feb. 5, 2015) [hereinafter Fiat CJ Appeal].

302. Fiat Judgment, supra note 8, para. 45; Starbucks Judgment, supra note 8, para. 159 .

303. Lux. ข. Comm'n, ECLI:EU:T:2019:670, para. 106. 
aid," 304 and there was no violation of the general principles of EU law nor the exclusive competences of the Member States. 305 As a result, the arguments of the appellants in this regard were unsuccessful. While the application of State aid was possible, 306 the GC issued a stark reminder to the Commission that it bore the burden of proof of each of its elements (a cue for its subsequent resolution to overrule two of the decisions). 307

\section{Demonstrating the Existence of a Selective Advantage}

\section{a. Embracing the Arm's Length Principle (With Caution)}

Once the general authority of the EC to invoke Article 107 TFEU had been established, the principal question was how it could be applied. The most contentious issue of the judgments was whether the Commission was entitled to use the ALP in particular, and OECD's guidance and principles in general, ${ }^{308}$ to consider whether a selective advantage not attainable through the ordinary tax system had been afforded. The implication of this recognition would be that intra-group transactions would be held to the same standard as market transactions between independent companies.

The Member States opposed the use of the ALP. ${ }^{309}$ Ireland insisted that, on the one hand, it was not part of Irish tax law, and on the other, "no freestanding obligation" to apply it stemmed from Article 107 TFEU or the European case law. ${ }^{310}$ In all of the appeals, the Commission argued that the CJ had previously embraced the ALP in the Forum 187 case. ${ }^{311}$ However, this was against a different contextual background. On that occasion, the CJ pondered the merits of a Commission decision relating to the Belgian tax regime for coordination centers. In the court's view, in order to determine the existence of an advantage in the calculation of the taxable profit on the basis of

304. Id. para. 108.

305. Id. para. 109; Apple Judgment, supra note 1, para. 116.

306. See, e.g., Neth. v. Comm'n, ECLI:EU:T:2019:669, para. 143.

307. Id. para. 196; Ir. v. Comm'n, ECLI:EU:T:2020:338, para. 100.

308. Ir. v. Comm'n, ECLI:EU:T:2020:338, para. 240.

309. Lux. v. Comm'n, ECLI:EU:T:2019:670, paras. 90, 94.

310. Ir. v. Comm'n, ECLI:EU:T:2020:338, para. 189.

311. Joined Cases C-182/03 \& C-217/03, Belg. v. Comm'n, ECLI:EU:C:2006:416 (June 22, 2006). 
the rules applicable to these centers, it would be necessary to compare the specific regime with the regular Belgian tax system, and with the profits of a corporation developing its activities under normal market conditions. The special rules led to subtracting certain expenses which would not have been deducted under conditions of free competition, hence an advantage existed. The advantage was also selective, because it was only available to certain companies. ${ }^{312}$

In the tax ruling investigations, the Commission saw in the ALP a possibility to identify the counterfactual-that is, to try to predict what might have happened to the beneficiary in the absence of the tax ruling. Without such comparator, the chances of successfully applying Article 107 TFEU would be non-existent, since demonstrating the conferment of an advantage would not be feasible. The GC accepted the validity of the ALP as a tool (rather than a general principle) to determine whether intragroup profit attribution "corresponds to the level that would have been obtained through carrying on that trade under market conditions." 313 According to the Court, while the countries may not have formally adopted the principle, they were members of the OECD, and in their capacity as OECD members they had reached a consensus on its pertinence. Specifically, it pointed out that the methodology followed to apply Irish tax law was consistent with the ALP.314 The GC was thus careful not to derive the application of the ALP from EU law, but rather understood it as a (tacitly or expressly) accepted principle of the Member States' OECD membership. The Court insisted that the EC had rightly pointed out that, while the OECD guidelines are not binding:

... those guidelines are based on important work carried out by groups of renowned experts, that they reflect the international consensus achieved with regard to transfer pricing and that they thus have a certain practical significance in the interpretation of issues relating to transfer pricing... 315

312. Id. paras. 94-95, 122-125.

313. Apple Judgment, supra note 1, para. 214.

314. Id. para. 218.

315. Starbucks Judgment, supra note 8, para. 155. 


\section{b. Burden and Standard of Proof}

In the context of tax measures, a selective advantage on a taxpayer is conferred when it is afforded "a reduction in the tax base resulting from a tax measure enabling [that] taxpayer to employ transfer pricing in intra-group transactions that did not resemble prices that would have been charged in conditions of free competition."316 The GG accepted the Commission's combined analysis of the existence of an advantage and selectivity, ${ }^{317}$ saying it was "not inconceivable". ${ }^{318}$ In fact, in tax rulings there would be a natural overlap: the measure would have to lead to a reduction in the amount of tax due under the ordinary tax regime (showing that the measure improved the financial situation of the recipient and conferred it an advantage), and this ordinary system is simultaneously what would apply to other taxpayers (proving that it is selective as it is not enjoyed by undertakings in a comparable legal and factual situation). .319

In the Fiat case, the GG found the EC was correct in establishing that the application of the TNMM had not been done correctly nor having regard to the ALP, because part of FFT's profits had been excluded. ${ }^{320}$ All of its capital, which was about ten times higher than that calculated in the APA, should have been considered, and a single rate should have applied to the entirety of that capital. If the sums had been done accordingly, the capital base would have been about sixty percent higher. ${ }^{321}$ As a consequence, FTT's liability was significantly lower than what it would have had to pay under the general Luxembourg tax system (the reference framework for the selectivity analysis), and an advantage had been approved. ${ }^{322}$

With regard to Starbucks, the first controversial matter was the Commission's position that the transfer pricing method

316. Ir. v. Comm'n, ECLI:EU:T:2020:338, para. 34.

317. For an analysis of advantage and selectivity (written prior to the GC's Fiat, Starbucks and Apple Judgments), see Saturnina Moreno González, State Aid and Tax Competition, 15 EUR. STATE AID L. Q. 556 (2016).

318. Ir. v. Comm'n, ECLI:EU:T:2020:338, para. 135.

319. Id. para. 136.

320. Fiat Judgment, supra note 8, para. 251.

321. Id. para. 276.

322. Id. paras. 280, 282, 286. 
relied on by the Netherlands was flawed. In fact, the GC accepted the application of the TNMM rather than the CUP, preferred by the EC. In this way, the GC afforded significant discretion over the interpretation of the ALP to the Netherlands in particular, and to the Member States in general should the issue come up again in another investigation. If the EC wanted to argue that the CUP was superior in this case, it should have demonstrated why. The disagreement between the EC and the Netherlands does not imply that the latter is mistaken. Moreover, the Commission failed to demonstrate that the transfer pricing method had been wrongly applied. The EC's analysis of the advantage requirement was scant and deficient. In this sense, it is not possible to argue that a company's tax burden has been reduced compared to what it would have been in the absence of the APA for simply failing to comply with the methodological requirement relating to the use of the CUP. In order to demonstrate an advantage, the Commission would have needed to calculate the results of the application of the CUP method. As a consequence, there was not enough evidence to prove, to the requisite standard, that the alleged errors did not result in a reliable approximation of a market-based outcome.

Moving on to Apple, the principal setbacks for the EC were that it did not correctly understand the burden of proof, and thus it did not, yet again, provide sufficient evidentiary support for its conclusions. In particular, the EC assumed that any profits for the Apple Group relating to IP licenses necessarily had to be allocated to ASI and AOE in Ireland, since they had no staff outside and thus no capacity to operate in any other jurisdiction. However, the Commission did not provide any evidence that the Irish companies had actually carried out the activities. ${ }^{323}$ The GC criticized the EC for not "conducting a more detailed analysis of the functions actually performed by the [Irish] branches," and for the assumption that those "functions had been performed by the permanent establishment." 324 The EC thus understood that, since the process of allocating profits to the head office looked suspicious, it was for Ireland to prove that the allocation had been adequately performed. In fact,

323. Apple Decision, supra note 2, paras. 242-243.

324. Id. 
according to the GC, the burden of proof was still on the EC to show the actual activities of the Irish branches. ${ }^{325}$

In addition, the EC made an error in the application of Irish law, and should have demonstrated that the allegedly faulty profit allocation led to a smaller tax burden as compared to the tax burden the company would have had to face in the absence of the APA. As a consequence of these issues, the GC concluded that the EC "did not succeed in showing to the requisite legal standard that there was a selective advantage for the purposes of Article 107(1) TFEU," and therefore the decision was annulled in its entirety. ${ }^{326}$

\section{STATE AID AS A TOOL TO COMBAT HARMFUL CORPORATE TAX PRACTICES: A CRITICAL ASSESSMENT}

"Of course, errors are not good for a chess game, but errors are unavoidable and in any case, a game without errors, or as they say 'flawless game,' is colorless. "' 27

The above quote from chess player Mikhail Tal was cunningly used by Dimitrios Kyriazis to describe Vestager's aggressive strategy. ${ }^{328}$ It ingeniously sums up the state of play in the EC's fight against harmful tax practices. Of the GC's rulings, the Fiat and Apple judgments have been appealed before the CJ. ${ }^{329}$ This means that the Commission has cut its losses in the case against Starbucks and accepted defeat. This might be a wise strategy. An appeal would need to refer to points of law, and the $\mathrm{EC}$ won on the key issues. It thus fulfilled its main objectives, and the irony of spending more EU taxpayers' money in what might prove to be a futile attempt at making a company pay (a relatively modest amount of) taxes would not be lost on the critics of its strategy. In the Apple case however, there is more at stake, and the Commission appears to think that it can still win. The headlines in the press relating to Apple's victory might give the amateur reader a sense of public humiliation for the

325. Id. recitals $495-504$.

326. Id. para. 507.

327. MiKHAIL TAL, THE LIFE AND GAMES OF MiKHAIL TAL (Everyman Chess, 2017). 328. Dimitrios Kyriazis, Playing Chess Like Commissioner Vestager, EuR. L. BLOG (Nov. 12, 2019), https://europeanlawblog.eu/2019/11/12/playing-chess-likecommissioner-vestager/\#comments [https://perma.cc/A47V-RATW].

329. Fiat CJ Appeal, supra note 301; Vestager, supra note 9. 
Commission. ${ }^{330}$ In fact, however, the main target audience of these investigations is not the general public. For the tax advisors of MNEs, and the countries enabling suspicious transfer pricing methods, the message will have been loud and clear, and will not fall on deaf ears even if the Commission ultimately fails to persuade the CJ.

Before drawing the final conclusions, this Part of the Article critically dwells on the main consequences of the progress made in the State aid battle against problematic tax rulings. It considers the issues on which the EC has claimed victory, the errors it may have committed, and the wider impact of these developments on EU law in general and EU competition law in particular.

\section{A. The Commission's Intended and Unintended Victories}

\section{The ALP in the Context of State Aid Law}

“... he came to the conclusion that you cannot depend on people, and that you can live in peace only if you keep them at arm's length." 331

In light of the recent judgments of the GC in relation to national tax rulings, it seems that the above conclusion reached by Jonathan Noel in Patrick Süskind's novel The Pigeon might prove helpful for multinationals. There is little doubt that the ALP is now very relevant in the context of State aid assessment, and disregarding it can lead to a finding of illegality of national decisions relating to direct corporate taxation under Article 107(1) TFEU.

Commentators have strongly criticized the incorporation of the ALP into State aid law. ${ }^{332}$ According to Michael McGrath, for

330. See, e.g., Samuel Stolton, Commission Loses Out in Apple-Ireland Tax Battle,

Announces Tax Abuse Clampdown, EURACTIV (July 15, 2020), https://www.euractiv.com/section/digital/news/commission-loses-out-in-appleireland-tax-battle-announces-tax-abuse-clampdown/ [https://perma.cc/Y33U-Q3CQ]; Javier Espinoza et al., Apple Wins Landmark Court Battle with EU over €14.3Bn of Tax Payments, Fin. Times (July 15, 2020), https://www.ft.com/content/1c38fdc1-c4b3-4835919d-df51698f18c4 [https://perma.cc/6RYD-ZBGX].

331. PATRICK SÜSKIND, The PigeON (Penguin 1988).

332. See, e.g., Luc de Broe, The State Aid Review against Aggressive Tax Planning: "Always Look a Gift Horse in the Mouth", 24 EC TAX REV., 290 (2016); Petter J. Wattel, Stateless Income, State Aid and the (Which?) Arm's Length Principle, 44 InTERTAX 791 
instance, "[t]he suspicion among many . . representatives in Ireland, including myself, is that State aid is being used as a veil to undermine Ireland's corporation tax system."333 In one of the most comprehensive studies to date in the field, Lovdahl Gormsen has expressed serious concerns about the incorporation of the ALP into Article 107 TFEU in particular, and the EU legal order in general. ${ }^{334}$ The imposition, which disregards whether the national systems of the Member States accept the ALP, amounts to forcibly incorporating not just the principle, but a specific version of it, into domestic tax law. She finds this to run "counter to the rule of law." 335 She also finds tax recovery to be "entirely disproportionate," 336 and warns about the confusion created by having two supranational bodies (the OECD and the EU) developing different transfer pricing standards. ${ }^{337}$

These arguments are certainly persuasive, and very legitimate. It should be borne in mind that, when Lovdahl Gormsen's work was published, the GC's views on this matter were not known, since the cases had not been decided. It is now clear that the GC opted to conclude that the ALP does not emanate from EU law, and is not an integral part of Article 107(1) TFEU. Instead, it is merely an instrument to allow for the practical application of this provision, and it comes into play because it is internationally recognized and familiar for the Member States in the context of their OECD membership. The acceptance of the ALP by the EU courts was almost unavoidable if State aid rules were to be considered relevant for the assessment of tax rulings.

(2016); Thomas Jaeger, Tax Concessions for Multinationals: In or Out of the Reach of State Aid Law?, 8 J. Eur. COMPETITIOn L. \& PrAC., 221 (2017).

333. Phillip Andrews, The Apple Case: An Irish Perspective, Materials of the New York State Bar Association Spring Meeting 2017 - Dublin, N.Y. STUDENT B. ASs'N (Mar. 29, 2017),

http://nysba.org/NYSBA/Sections/International/Events/2017/Dublin/Coursebook/

State\%20aid\%20panel\%20paper_Apple_21\%20April\%202017.pdf

[https://perma.cc/B28M-4F4E].

334. See generally GORMSEN, supra note 17. See also discussion supra Part V.A.1.

335. GORMSEN, supra note 17.

336. GORMSEN, supra note 17 , at 2, 144-45 (and throughout the book).

337. Id. 
It is also important to remember here, besides the principle of supremacy, ${ }^{338}$ the CJ's clarifications regarding the nature of the EU. In particular, the Union "constitutes a new legal order of international law for the benefit of which states have limited their sovereign rights, albeit within limited fields." 339 In light of this recognition, it not far-fetched to conclude that, if a pivotal piece of that legal order could be rendered inapplicable to situations where it would otherwise be perfectly relevant, the EU institutions would be afforded significant leeway to look for effective tools to fix that. After all, the stability and economic prosperity of the Union and its citizens can clearly be affected by any practices that significantly drain the resources of the Member States. Moreover, the EU law enforcement system offers stark assurances in relation to the protection of the rule of law. The EC decisions have been subject to thorough judicial review, thus dissipating most of the concerns raised by Lovdahl Gormsen.

The ALP may not be a perfect parameter for establishing the existence of an advantage, but no better indicator has thus far been proposed. Its limitations must be accepted. The OECD itself has recognized that "transfer pricing is not an exact science but does require the exercise of judgment on the part of both the tax administration and taxpayer." 340 It seems rather exorbitant to ask the EC to apply mathematical-like parameters to something that is indeed inexact. Moreover, the GC's recent judgments in Starbucks and Apple confirm that Member States have leeway when choosing their preferred transfer pricing methodology to comply with the ALP. Should the EC want to challenge their choice, it alone bears the burden of proof with regard to the creation of an advantage.

In relation to the confusion raised by the parallel work of the OECD and the EU, it should be noted that they both work

338. See supra Part IV.A. See also Case C-183/08, Glaxo Wellcome GmbH \& Co. KG v. Finanzamt München II, 2009 ECLI:EU:C:2009:559, para. 34 (Sept. 17, 2009).

339. Case C-26/62, NV Algemene Transp.- en Expeditie Onderneming van Gend \& Loos v. Neth. Inland Revenue Admin., 11 (Feb. 5, 1963).

340. OECD, Review of Comparability and of Profit Methods: Revision of Chapters I-III of the Transfer Pricing Guidelines (July 2010), https://www.oecd.org/ctp/transfer-pricing/45763692.pdf [https://perma.cc/8MJ7RBVL]. 
together in this field. ${ }^{341}$ The work of the OECD often refers to that of the EU, and there are frequent references to OECD publications in the EU's initiatives. Therefore, rather than confusion, the adoption of similar principles might in fact lead to greater convergence and clarity. Since the Member States of the EU are also OECD members, they would not be unfamiliar with the ALP, regardless of whether they have actually taken steps to embrace it in their national laws.

\section{Pushing for National Legal Reform}

The State aid route for fighting tax avoidance is only a piece of a broader strategy towards fair corporate taxation in the EU. The legislation adopted to harmonize national tax regimes and preclude tax avoidance was covered above. ${ }^{342}$ Tax harmonization is naturally the preferred way of tackling these issues, since it is the only way to avert the temptation to engage in BEPS altogether. ${ }^{343}$ At the same time, the State aid rules might represent a more practical option, given the broad powers conferred on the Commission by EU competition law provisions. Crucially, the EC investigations into the tax practices of MNEs have triggered the introduction of legislative changes in the countries where the APAs were issued. Not only did Ireland eliminate the double Irish sandwich shortly after the EC started looking into Apple's tax rulings. ${ }^{344}$ Luxembourg and the Netherlands, among others, announced reforms to prevent these situations from arising in the future-a move Vestager has welcomed. ${ }^{345}$ The recovery of potentially unpaid taxes is less of a

341. See supra note 209 and the many references to the work of the OECD in the Fiat, Starbucks and Apple Decisions.

342. See supra Part IV.B.

343. In relation to the Apple Decision, Lamadrid suggested that the "underlying problem [was] a political one (tax competition due to lack of tax harmonisation) and should arguably be better tackled at the root." Alfonso Lamadrid, On the State Aid Apple Decision, CHILliN' COMPETITION (Sept. 1, 2016), https://chillingcompetition.com/2016/09/01/on-the-apple-state-aid-decision/ [https://perma.cc/V3WZ-T2YQ].

344. Phillips Erb, supra note 179.

345. European Commission Press Release IP/18/5831, State aid: Commission Investigation did not find that Luxembourg gave selective tax treatment to McDonald's 19,
hept.
https://ec.europa.eu/commission/presscorner/detail/en/IP_18_5831 [https://perma.cc/9YNK-PMJS]. See also Mehreen Khan, Dutch Set Out Plan to Counter 
priority than ensuring that others are unable to resort to similar tricks. The pressure exerted by the EC's multiple investigations is thus accomplishing its central goal.

\section{Reducing Predictability}

The usefulness of tax rulings for attaining legal certainty was highlighted earlier in this Article. ${ }^{346}$ Commentators have expressed concerns about the unpredictability caused by the interference of State aid, and the incorporation of the ALP. ${ }^{347}$ Yet the importance of certainty may be somewhat overrated, and the idea that risk can be entirely removed is at best naïve. Already in the 16th century, the celebrated philosopher Voltaire said that "doubt is not very pleasant, but certainty is absurd." 348 Extrapolating this to the tax world, as Rainer Niemann has pointed out:

... there is tax uncertainty even if the tax law remains unchanged and if an investor has already made all economic decisions which are relevant for taxation. The reason is that taxpayers, fiscal authorities and tax courts may interpret tax laws and economic facts differently. ${ }^{349}$

The acknowledgment that APAs may be declared illegal by virtue of State aid does not serve to annihilate certainty. Rather, it is a stark reminder of its limits. Not even the preapproval of the relevant tax authorities may be enough to ensure legality. Moreover, the developments to date highlight that tax rulings

\footnotetext{
Tax-Haven Reputation, FIN. TIMES (Feb. 27, 2018), https://www.ft.com/content/ef9b87ac-1af5-11e8-aaca-4574d7dabfb6 [https://perma.cc/36PS-Q6JC]; Emre Peker, McDonald's Avoids Fines as Europe Rules Its Tax Deal Is Legal, WALL ST. J. (Sept. 19, 2018), https://www.wsj.com/articles/mcdonalds-avoids-fines-as-europe-rules-its-tax-deal-islegal-1537352124 [https://perma.cc/7Q8H-FTNK]. It should be noted that this piece mistakenly understands that companies can be fined if their tax rulings are contrary to State aid law. This is not the case: they are simply asked to pay back the aid received (in these cases the unpaid taxes).

346. See supra Part III.A.

347. Tony Joris \& Wout de Cock, Is Belgium and Forum 187 v. Commission a Suitable Legal Source for an EU “At Arm's Length Principle”?, 4 EUR. STATE AID L. Q. 607 (2017).

348. The French original is: "Le doute n'est pas un état bien agréable, mais l'assurance est un état ridicule". Voltaire, Lettre LXX de M. de Voltaire au Price Royal de Prusse (Nov. 28, 1770), in Oeuvres Completes DE VOLTAIRE VOL 66 (Société LittéraireTypographique 1784).

349. Niemann, supra note 127 , at 2.
} 
will only be deemed unlawful if they enable MNE groups to misuse transfer pricing to unduly reduce their tax bills. This is an objectionable practice that should be discouraged. If nipping legal certainty renders these tax schemes less attractive, then this ought to be considered a positive by-product of the EC's strategy.

\section{Unintended Outcomes: Probing Resilient Narratives about}

\section{EU Law}

The significance of Apple's GC victory has been unquestionably magnified by the media attention the case has attracted. One accidental positive outcome of the saga is that it has shone an unusual spotlight on a Commission loss. And not just any loss at that-one against a prominent US tech company. This development inadvertently casts doubt on some of the questionable narratives relating to EU competition law enforcement which are all too often drilled into the general public. The focus here is on two narratives: technology protectionism, and the rigor (or lack thereof) of EU judicial review.

\section{a. Technology Protectionism in the Application of EU Competition Law}

Just days before the Apple decision was announced, the US Department of Treasury issued a White Paper entitled The European Commission's Recent State Aid Investigations of Transfer Pricing Rulings, 350 putting forward three concerns vis-à-vis the investigations into the tax practices of MNEs: (1) the approach is new and departs from established case law and EC practice; (2) there should not be an attempt to retroactively recover purportedly unpaid taxes; and (3) the rationale behind the most recent cases is at odds with international norms, thereby undermining the international tax system. ${ }^{351}$ According to the

350. U.S. DeP'T of THE TREASURY, The European Commission's Recent STATE Aid InVestigations OF Transfer Pricing Rulings (Aug. 24, 2016), https://www.treasury.gov/resource-center/tax-policy/treaties/Documents/WhitePaper-State-Aid.pdf [https://perma.cc/6E7M-8RXN].

351. Id. at 1 . 
US administration at the time, the EC's decisions risked creating "an unfortunate international tax policy precedent." 352

Recent investigations in various spheres of competition law (particularly State aid, merger control, and the abuse of dominance) have rubbed salt into the technology protectionism wound, that is, the idea that the law may be tactically enforced against powerful foreign tech firms so as to favor EU market players. ${ }^{353}$ In 2015, then-President Barack Obama suggested that some of the investigations against US firms were mainly, if not exclusively, commercially driven: "[w]e have owned the internet. Our companies have created it, expanded it, perfected it in ways that [Europeans] can't compete. And oftentimes what is portrayed as high-minded positions . . . is just designed to carve out . . commercial interests." 354 President Donald Trump was curter when he said to former EC President Jean-Claude Juncker of Vestager: "your tax lady, she really hates the US." 355

As Ramsi Woodcock has pointed out, "[t]he casual observer could be forgiven for thinking that European antitrust regulators have declared war on American tech giants." 356 This is because Vestager has not been "afraid to pit the Commission against American behemoths and European powerhouses," 357

352. Rupert Neate, US Warns Europe Over Plan to Demand Millions in Unpaid Taxes

from Apple, GUARDIAN (Aug. 24, 2016),
https://www.theguardian.com/technology/2016/aug/24/apple-taxes-europeancommission [https://perma.cc/6SX3-6MU4].

353. See Murad Ahmed, Obama Attacks Europe Over Technology Protectionism, FIN. Times (Feb. 16, 2015), https://www.ft.com/content/41d968d6-b5d2-11e4-b58d00144feab7de [https://perma.cc/HTF7-XP8L]. The concept of technology protectionism has also been discussed in the context of the granting of IP rights. See, e.g., GAÉTAN DE RASSENFOSSE \& EMILIO RAITERI, TECHNOLOGY PROTECTIONISM AND THE PATENT System: StRategiC TeChNOlogies IN China (July 1, 2016), http://ssrn.com/abstract=2803379 [https://perma.cc/4J9Y-R357].

354. Kara Swisher, White House. Red Chair. Obama Meets Swisher., RECODE (Feb. 15, 2015), https://www.vox.com/2015/2/15/11559056/white-house-red-chair-obamameets-swisher [https://perma.cc/KX6Z-35GY].

355. Paul Kirby, Margrethe Vestager-Denmark's EU "Tax Lady" Taking On Corporate Giants, BBC News (July 18, 2018), https://www.bbc.com/news/world-europe-32410052 [https://perma.cc/HQV6-N6GU].

356. Ramsi Woodcock, EU's Antitrust War on Google and Facebook Uses Abandoned American Playbook, CONVERSATION (July 14, 2017), http://theconversation.com/eusantitrust-war-on-google-and-facebook-uses-abandoned-american-playbook80659? utm_source=twitter\&utm_medium $=$ twitterbutton $\quad[$ https: $/ /$ perma.cc $/ Y 6 U 3-$ $427 \mathrm{~T}]$.

357. Kyriazis, supra note 328. 
yet the above criticisms are largely unfounded. Countless headlines refer to Europe's war against big tech, focusing on the "who" (Google, Broadcom, Amazon, Intel) rather than the "why" (their market makes their behavior particularly likely to harm the competitive process). As I have argued elsewhere, EU and US antitrust policy are fundamentally different, and have increasingly diverged over the past four decades. ${ }^{358}$ Issues like market power and tax avoidance may pose a threat to the former's core values, and EU enforcers are prone to taking action to curb any detrimental effects. Moreover, there are plenty of investigations targeting European companies, ${ }^{359}$ and therefore the argument that they are somehow afforded a special treatment is feeble, if not baseless.

Against this background, Alfonso Lamadrid has highlighted the important political consequences of the Fiat and Starbucks Judgments, which have since been strengthened by the Apple ruling:

... the credibility of the Court and of the EU system may be reinforced by the fact that-fortuitously-it was only the US company (and the Netherlands) getting out of the hook, not the European one (and Luxembourg). .360

\section{b. The Thoroughness of the Judicial Review of EC Decisions}

Another powerful narrative shaken by the Apple judgment relates to the absence of rigorous judicial review of EC decisions. Prof. Damian Chalmers encapsulated this position when he said that " $[\mathrm{t}]$ he $[\mathrm{CJ}]$ has too much institutional investment in the development of the European Union to discharge its checks and balances role successfully." "361 In Apple, the GC carried out a 37.

358. The Antitrust "F" Word: Fairness Considerations in Competition Law, supra note

359. See, e.g., Case C-457/10 P, AstraZeneca AB \& AstraZeneca plc v. Comm'n, ECLI:EU:C:2012:770, (Dec. 6, 2012); Commission Decision on Case M.8677 Siemens/Alstom, COM (2019) 921 final (Feb. 6, 2019).

360. Alfonso Lamadrid, The Fiat and Starbucks Judgments, CHILLIN' COMPETITION (Sept. 25, 2019), https://chillingcompetition.com/2019/09/25/the-fiat-and-starbucksjudgments/ [https://perma.cc/S4NS-EGUD].

361. Damian Chalmers, The European Court of Justice is Now Little More than a Rubber Stamp for the EU. It Should Be Replaced with Better Alternative Arrangements for Central Judicial Guidance, LSE EUROPP BLOG, (Mar. 8, 2012), 
comprehensive analysis of the economic evidence presented by the Commission, and pondered whether there was sufficient support for the outcome. ${ }^{362}$ Ultimately, it was not afraid to rule against the EC even when the stakes were so high. This is proof, if proof were needed, that "the European system of judicial review works, no matter the nationality of the companies affected and the political interests at stake." 363 While the GC was at times critical of the tax schemes endorsed by the Netherlands and Ireland, it was adamant that its judgments would not be a case of "doing the right thing for the wrong reason." 364 While the dealings indeed looked somewhat concerning, if the required evidentiary burden to annul them is not met, then they cannot be declared unlawful.

\section{B. Sharpening the Commission's Axe: Considerations for Improvement}

At the time of writing, the errors on which the Commission is basing its appeal of the GC's Apple judgment had not been made public. ${ }^{365}$ Importantly, the Commission has already been proved right on the main points of law, and the losses before the GC are by no means catastrophic. On the contrary (pending the CJ's Fiat and Apple judgments), 366 it now has the express blessing of the EU judiciary to proceed with its investigations into APAs. Likewise, it has skillfully made use of its competences to exert pressure on the EU Member States to take action against harmful tax practices.

Irrespective of these accomplishments, if the EC continues to score losses for failing to meet the required evidentiary burden, the media will feast on its defeats, and there is a risk that its strategy will lose credibility in the long run. This may in part be the reason why the EC has finally decided to appeal its most publicized loss. However, perhaps more importantly, the

\footnotetext{
https://blogs.lse.ac.uk/europpblog/2012/03/08/ecj-rubber-stamp-replacement/ [https://perma.cc/UJ3U-NPAU].

362. Apple Judgment, supra note 1.

363. Espinoza et al., supra note 6.

364. Spencer Weber Waller, The Political Misuse of Antitrust: Doing the Right Thing

for the Wrong Reason, COMPETITION POL'Y INT'L (July 16, 2020), https://www.competitionpolicyinternational.com/the-political-misuse-of-antitrustdoing-the-right-thing-for-the-wrong-reason/ [https://perma.cc/6RU6-T8E6]. 365 . Vestager, supra note 9.

366. Fiat CJ Appeal, supra note 301; Vestager, supra note 9.
} 
Commission ought to reflect on what it can do to go the extra mile and either gather sufficient proof, or be more selective when choosing its investigations. Particularly, it needs to carefully consider the reasons why, in the GC's eyes, it fell short of demonstrating the existence of a selective advantage in both Starbucks and Apple. The best way to go about this would be to compare the evidence presented in Fiat with that of the other cases. As Lamadrid has explained:

the Commission [may be required] to do a greater job when Member States do worse. In other words, the Commission cannot simply assume that because the Member State acted in a seemingly arbitrary manner the outcome was wrong. ${ }^{367}$

The pivotal issue is that only in Fiat did the EC manage to demonstrate a deviation from the ALP on the part of the Luxembourg tax authorities when issuing the tax ruling in favor or FFT. It did so on the basis of laborious analysis which effectively showed that, in a counterfactual scenario where the APA had not been granted, FFT's tax bill would have been significantly heavier. ${ }^{368}$ Overall, the EC may have been overly complacent about the burden of proof and the evidentiary burden. In the Starbucks case, the EC could have attempted to show how the application of its preferred pricing method would have led to a significantly different, less advantaged outcome. In Apple, an analysis of the actual activities of ASI and AOE might have sufficed to prove the arbitrary profit allocation process. All of this would naturally have required significant efforts, and it may be true that, " $[\mathrm{w}]$ hen you are winning even when you lose, there is no point in trying too hard." 369

\section{CONCLUSION}

US Supreme Court Justice Oliver Wendell Holmes Jr. once said that "taxes are what we pay for civilized society." 370 Corporate tax avoidance and harmful tax competition adversely

367. Lamadrid, supra note 343.

368. Fiat Decision, supra note 140.

369. Dimitrios Kyriazis, Why the EU Commission Won't Appeal the Starbucks Judgment, MNE TAX (Dec. 10, 2019), https://mnetax.com/why-the-eu-commission-wont-appealthe-starbucks-judgment-37043 [https://perma.cc/KME9-P9UY].

370. These words are engraved at the entrance of the headquarters of the US Internal Revenue Service. 
affect economic prosperity, and give rise to tensions between countries. Differences in tax rates and legal loopholes have enticed MNE groups branched out over various jurisdictions to play around with their IP-associated profits so as to shrink their fiscal obligations. Around the world, governments are joining forces to combat these practices, aware that they may only be eradicated through coordinated transnational efforts. Since the 1990s, the OECD and the EU have acted as key fora for springing into action. Keeping an eye on each other, they have worked towards establishing fundamental principles and issuing valuable guidance. The EU has also succeeded in compelling its members to adjust their tax laws to thwart transfer mispricing and double non-taxation, thereby tackling the root cause. The resulting harmonized legislative landscape paints a promising (albeit EU-wide only) picture of a fairer system of direct corporate taxation.

Since 2013, the EC has further attempted to counter the wrongs of the past by sending MNEs invoices for purportedly unpaid taxes, using State aid law to target tax rulings. A preliminary look at the GC's Starbucks and Apple judgments might suggest that, in taking on these giants, the Commission bit off more than it could chew. In practice however, this Article has shown that the outcome may in fact be a windfall. The EU judiciary has given the green light to the State aid route, and has furnished the EC with a fundamental tool-the ALP-to effectively apply the Article 107(1) prohibition to tax rulings. The Commission can thus use an instrument over which it has exclusive competence to meddle in a field that had been almost entirely cordoned off by the Member States. This achievement in and of itself has put a pit in the stomach of both MNEswhose questionable tax schemes have been exposed-and the countries enabling these arrangements. The Member States under investigation have vowed to change their laws, and ironically, by winning the appeals, they lost out on significant sums of money. ${ }^{371}$ The Commission's resounding defeats are

371. Dara Doyle \& Peter Flanagan, Ireland Loses Apple Billions, but Wins Tax Vindication for Now, BLOOMBERG (July 15, 2020), https://www.bloomberg.com/news/articles/2020-07-15/ireland-loses-apple-billionsbut-wins-tax-vindication-for-now [https://perma.cc/SFG7-SGYX]. 
also a poster for the thoroughness and impartiality of the EU legal system.

To really pull off a royal flush, the Commission must now fight tooth and nail to meet the required evidentiary burden. It needs to show that Fiat was not the exception that proves the rule and that State aid cases against tax rulings can be won. The deterrent effect of the tactic might otherwise wear off soon. The recent implementation of the Anti-Tax Avoidance Directive is likely to avert many instances of corporate tax malpractice, reducing the need to prolong the offensive against tax rulings. For the time being however, a truce is unlikely. 
468 FORDHAM INTERNATIONAL LAWJOURNAL］[Vol. 44:2 